\title{
De-facto marine protection from a Navy bombing range: Farallon De Medinilla, Mariana Archipelago, 1997 to 2012.
}

\author{
Stephen H. Smith and Donald E. Marx Jr. \\ U.S. Navy-Space and Naval Warfare Systems Center Pacific \\ Energy and Environmental Sciences Group
}

\section{Corresponding Author: Stephen H. Smith \\ Office: 1-808-472-1405}

Fax: 1-808-474-5419

Email: Stephen.h.smith@navy.mil

Postal Address: SPAWAR SSC, Code H56. 2293 Victor Wharf Access Road. Building 992. Pearl City, HI. USA 96782

\subsection{Introduction}

\subsection{Marine Protected Areas}

Many investigators have shown that near shore marine ecosystems around the world are subject to increasingly adverse impacts from anthropogenic factors including unsustainable fishing, improper/inadequate waste disposal, coastal development, introduced species, anchor damage, and tourism, e.g. jet skiing, collection of marine organisms, recreational snorkel and scuba diving and reef walking (Smith 1988; Harriott 1997; Van Treech and Schumacher 1998; Daszak et al. 2000; Jackson et al. 2001; Worm et al. 2006; Shivlani 2007; Carpenter et al. 2008; Sheppard et al. 2012; Yates et al. 2014). Direct and indirect anthropogenic impacts, coupled with natural phenomena have placed coral reefs and their associated flora and fauna in a precarious position worldwide (Brainard et al. 2011; PIFSC 2014). Marine Protected Areas (MPAs) have become more numerous since the 1980s. However, their effectiveness is dependent upon many factors including location, size, and the degree to which the MPA's regulations are actually enforced (Kerwath et al. 2008; Sheppard et al. 2012). Halpern (2003), Selig and Bruno (2010) and Roberts et al. (2001) have shown that when enforced, protected areas conserve the structure and function of local ecosystems and provide spill over benefits to adjacent areas. During the last decade, most publicly accessible coastal areas are declining, but in contrast marine natural resources in areas under control by the U.S. Department of Defense (DoD), with limited or no public access, are thriving and/or in significantly better condition than adjacent areas (Smith et al. 
2006; Stein et al. 2008). Many DoD properties support three times the densities of Endangered Species Act (ESA) status species and imperiled species as are found on lands administered by other federal and state agencies (Stein et al. 2008). Marine resources within these DoD controlled areas are generally healthier, larger and more abundant than those outside. These areas are serving as de-facto MPAs.

At DoD locations with restricted access, many of the key stressors common to public coastal areas are absent or greatly reduced. Of course, some DoD sites have their own set of unique stressors, but in the case of the site investigated in this paper, the net benefit of restricted public access clearly outweighed any adverse impacts related to DoD activities.

\subsection{Farallon De Medinilla - General Geography}

Farallon De Medinilla (FDM) is located in the Mariana Archipelago, a chain of 15 volcanic islands approximately 2,300 km south of Japan and 3,600 km west southwest of Hawaii (Fig. 1).

Politically/legally FDM is within the Commonwealth of the Northern Mariana Islands (CNMI). FDM is 1.6 $\mathrm{km}$ long with an area approximately $72 \mathrm{ha}$. It is $278 \mathrm{~km}$ north of Guam, $65 \mathrm{~km}$ north of Saipan (Fig 1). The southern portion of the Mariana Archipelago includes the islands of Guam, Saipan, Tinian, Aguijan, Rota and FDM. These islands all have an extensive limestone cap, primarily Mariana Limestone, which covers their volcanic core. Islands within the northern portion of the archipelago are volcanically active and lack a limestone cap. There are no surface water bodies or streams on FDM and it is surrounded by steep, unstable sea cliffs (Fig. 2 and 3). Terrestrial surveys and literature reviews have never found evidence that FDM was inhabited (Whistler, 1996).

The Mariana Archipelago is seismically very active, e.g. the U.S. Geological Survey recorded 245 earthquakes with magnitudes up to 5.7 between 1999 and 2010. Tsunamis affect the archipelago from both locally generated seismic events as well as events in Japan, the Philippines and Indonesia. The island of Anatahan is an active volcano and is located only $60 \mathrm{~km}$ from FDM. In addition, FDM is located within one of the most active typhoon regions in the world (Fig 4), and is normally subject to high waves and strong current conditions.

\subsection{Military Training Zones}

Portions of FDM have been utilized as a live and inert firing and bombing range since 1971. The island is divided into four zones, for training purposes (Fig. 5).

\subsection{Biogeography}

FDM falls within the Indo-Pacific Biogeographic Region and the Mariana Islands sub-ecoregion.

Richmond et al. (2008) lists over 375 Scleractinian corals and 1,000 fish species within the archipelago. Its marine community, like those of the northern islands, is less complex than those around the larger islands, such as Guam due to its small size, the lack of shallow water, the absence of any lagoons, reef flats or fringing reefs. Richmond et al. (2008) noted that five key limiting factors affect marine flora and fauna in the northern portion of the archipelago: 1) unfavorable bathymetry, 2) lack of suitable substrate on which corals can recruit and grow, 3) high wave energy conditions, 4) re-suspension of 
volcanic ash and, 5) volcanic eruptions. Of these, high energy conditions and a lack of suitable substrate are likely to be the most significant. Much of the nearshore environment at FDM consists of naturally relatively barren rock or coarse rubble and sand (Table 1). Of note, are the presence of numerous boulders and cliff blocks (> 20 m maximum dimension) and dozens of caves. Nearly all the Scleractinian corals are present on the tops of the boulders and cliff blocks, on a submerged spur at the southern tip of the island or on a shelf area of Z3E (Fig. 5). In spite of these limiting factors, FDM supports diverse and abundant flora and fauna with fin fish biomass comparable to or exceeding those recorded by the National Oceanic and Atmospheric Administration (NOAA) Pacific Islands Fishery Science Center Mariana Archipelago Reef Assessment and Monitoring Program (MARAMP) during its archipelagic surveys conducted between 2003and 2009 (PIFSC 2014). Due to safety constraints, no MARAMP surveys were conducted at FDM

Table 1. Major habitat types at FDM.

\begin{tabular}{|l|c|c|}
\hline Major Habitat Types & $\begin{array}{c}\text { Approximate Rank (by area covered) } \\
\text { In 1-30 m depth range }\end{array}$ & $\begin{array}{c}\text { Approximate Coral Cover } \\
\text { Scleractinia }\end{array}$ \\
\hline Coarse sand \& rubble & 1 & $<0.5 \%$ \\
\hline Boulders $<1 \mathrm{~m}$ max dimension & 6 & $<1 \%$ \\
\hline $\begin{array}{l}\text { Cliff blocks } \\
\text { To }>20 \mathrm{~m} \text { max dimension }\end{array}$ & 4 & $5 \%-50 \%$ \\
\hline $60^{\circ}-90^{\circ}$ bedrock slopes & 3 & $<1 \%-30 \%$ \\
\hline $20^{\circ}-60^{\circ}$ bedrock slopes & 2 & $<1 \%->60 \%$ \\
\hline Caves & 5 & $\mathrm{Nil}$ \\
\hline
\end{tabular}

Examples of FDM habitat types are shown in Figures $6-9$.

\subsection{Materials and methods}

Marine surveys at FDM presented significant challenges: remote location, generally adverse sea states, strong currents (speeds up to $7 \mathrm{~km} / \mathrm{h}$ have been measured), on-going use of the island as a military training range, and the presence of unexploded ordnance on the sea floor. Table 2 lists the known marine biological surveys which have been conducted at FDM.

Table 2. Marine biological surveys conducted at FDM $1997-2012$.

\begin{tabular}{|l|c|}
\hline $\begin{array}{c}\text { Survey Team } \\
\text { Affiliation of } \\
\text { Marine Biologists }\end{array}$ & Year/Month Surveyed \\
\hline U of Hawaii (1) & July 1997, July 1999; July 2000, July 2001, \\
NOAA (1) & Oct. 2002, July 2003, July 2004 \\
USFWS (1) & (each survey 4 days) \\
CNMI DFW (1) & Nov. 2005, Sept. 2006, Sept 2007, \\
\hline Navy (2) & $\begin{array}{c}\text { Oct. 2008, Aug./Sept. 2009, Oct. 2010 } \\
\text { 2011 (No Survey), Aug. 2012 } \\
\text { (each survey 6 days except 2009) }\end{array}$ \\
\hline
\end{tabular}


The U.S. Navy (Navy) funded the initial survey in 1997 by the University of Hawaii, NOAA, U.S. Fish and Wildlife Service, and the Commonwealth of the Northern Mariana Islands (CNMI) Division of Fish and Wildlife. These same four biologists conducted subsequent surveys through 2004 . Since 2004, all surveys were performed by the authors. Diving and safety support for all surveys was provided by Navy Explosive Ordnance Disposal Unit Detachment Marianas (EOD DET MARI).

Primary objectives of all surveys were to assess conditions of the nearshore habitats and key species, changes in the latter over time, and to estimate the extent of environmental change that could be attributed to anthropogenic factors and determine what, if any, mitigation measures for training would be effective and feasible.

\subsection{Methods utilized}

The methods used in all 14 surveys were judged to be comparable. The Supplementary Information Appendix 1 describes the methods utilized between 1997 and 2004. Safety and liability concerns resulted in the shift to an all Navy survey team in 2005. These relied on scuba, sometimes assisted with Diver Propulsion Vehicles (DPVs). Each year after 2005, the entire island was circumnavigated underwater at multiple depths, to $31 \mathrm{~m}$. Dive tracks covered, as closely as possible, the same areas each year (Fig. 5), and one or more of the same EOD team members participated each year (1999 - 2012) which helped to ensure the same areas were assessed. Lateral visibility averaged $30 \mathrm{~m}$, but ranged from 7 to $70 \mathrm{~m}$. The biologists swam in parallel, usually spaced 15 to $20 \mathrm{~m}$ apart depending upon sea floor contours and visibility. At least one EOD diver was located between the biologists. Therefore, a wide surveillance swath of 75 to 100 m was completed on most dives.

\subsubsection{Physical factors}

During all 14 surveys, the physical environment was examined for evidence of damage, including: craters, blast pits, peeled layers of rock, cracked, broken or fragmented rocks, boulders and coral, freshly derived terrestrial rock fragments or boulders, ordnance fragments, intact bombs, rockets or missiles, fishing line, sinkers, hooks, traps, spears, anchors, and chain/line. The locations and dimensions of all were recorded. Where possible, the ordnance items were identified and aged by EOD personnel.

\subsubsection{Algae}

From 2005 Cyanophyta/Cyanobacteria (Blue-green algae) were evaluated along with the three major functional groups, as described by Littler and Littler (2003): turf algae, crustose corallines (CCA), all other algae. Use of the term turf algae is sometimes inconsistent and often disputed (Connell et al. 2014). As used here, turf algae, were the multi-species assemblage of diminutive, generally filamentous algal species with heights generally less than $5 \mathrm{~cm}$.

\subsubsection{Coral}


Corals were field identified to the lowest possible taxa during all 14 surveys. From 2005 onward, data was recorded on: 1) partial or complete mortality of individual colonies, 2) mucus production, 3) coral diseases, 4) predation, 5) evidence of macro-bioeroders, and 6) bleaching.

Distinguishing between natural and anthropogenic damage was focused on. Partial mortality (surface lesions or dead areas) can be an effective indicator of stress (Hughes and Jackson 1980, Riegl 1995). Mucus production in Scleractinia is also an indicator of stress from pollutants, sedimentation, etc. (Stafford-Smith and Ormond, 1992; Stafford-Smith, 1993; Wild et al. 2005). Bruno et al. (2003) and Sutherland et al. (2004) demonstrated that corals are more vulnerable to disease when they are under environmental stress. An assessment of predation was made based upon action by Crown-of- Thorns starfish (COTS), gastropod corallivores such as Drupella sp., Parrotfish bite scars and macro-bioeroders (e.g. boring sponges). Cooper et al. (2008) correlated diminished water quality with high densities of macro-bioeroders. Bleaching (loss or reduction in the symbiotic zoothanthellae) was evaluated by placing coral into one of four categories: 1) $<10 \%$ bleached, 2) $>10 \%<50 \%$ bleached, 3 ) $>50 \%$ bleached, and 4) bleached and partially or completely overgrown with algae.

\subsubsection{Macroscopic benthic invertebrates}

Opportunistic counts were made of selected fishery target species: giant clams (Tridacna sp.), top shells (Trochus niloticus), spider conch (Lambis sp.), and sea cucumbers (all species). A special effort was made to record any of the coral-eating Crown-of-Thorns starfish (Acanthaster planci), hereafter referred to as COTS. Subjective observations of sea urchins and feather stars were also made.

\subsubsection{Sharks, Rays and Bony Fishes}

During all 14 surveys, specimens were identified to the lowest possible taxa; identification was based upon Myers (1991), Randall (2001 and 2007). Estimated sizes were recorded as total length (TL), except for rays whose maximum disk width was recorded. Prior to 2005, individual species abundance was recorded as abundant (>25 individual sightings/30 minutes), common $(15<25)$, occasional (5 -14), and rare $(<5)$. Beginning in 2005, selected individual species abundance estimates were made, and selected family abundances were combined. Species and families assessed by the authors are shown in Table 4 . Appropriate scaling was applied to normalize abundance estimates to a 30 minute observation period. In addition, actual counts of sharks, rays, and selected bony fish were made.

Table 3 . Fish species and families semi-quantitatively assessed from 2005 through 2012.

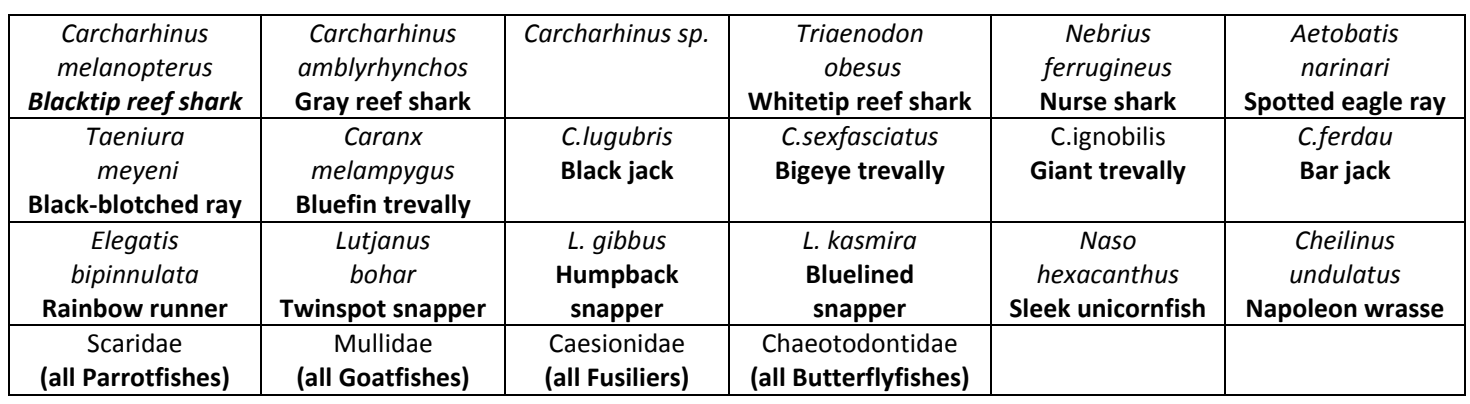


Schooling species which were observed to aggregate at particular locations each year were repeatedly photographed and fish counts were made from the photos. Those counts were compared with the stationary visual counts made at the aggregation sites.

\subsubsection{Sea turtles}

Five species of sea turtles are recorded from the Mariana Archipelago, but only two species were seen during the 1997 to 2012 surveys. All sea turtles observed from the dive boat and underwater were recorded. When possible, the species, estimated straight carapace length $(<50 \mathrm{~cm},>50<100 \mathrm{~cm}, \geq 100$ $\mathrm{cm}$ ), sex, apparent health, distinguishing features (scars, barnacles, tumors), and the turtle's activity when first observed (swimming, resting, and feeding) were recorded.

\subsection{RESULTS}

It had previously been concluded (DoN 2003) that no significant changes in species composition, diversity or health were detected in the flora or fauna from 1999 through 2003, and differences seen in 2004 were attributed a typhoon (DoN 2004). See Appendix 2 for additional information on these surveys.

From 2005, a special effort was made to conduct the surveys as soon as possible and always less than 10 days after Navy training events were completed. The 2008 and 2010 surveys were performed 36 and 55 hours after training stopped.

\subsubsection{Physical conditions}

Minor physical disturbances from the training activities and from undetermined causes were observed during every survey. Direct ordnance impacts on the submerged physical environment, clearly attributable to training activities, were detected in 2007, 2008, 2010, and 2012. Indirect impacts, such as fresh/uncolonized rock and ordnance fragments blasted off the island were detected every year. Most ordnance fragments were less than $5 \mathrm{~cm}$ in their maximum dimension; intact/partially intact ordnance items sighted on the sea floor nearly always had deep scratches in their cases, lacked fins or tail assemblies and/or were bent. It was concluded that the substantial majority of ordnance items on the sea floor, initially hit the island and then skipped or ricocheted off or were eroded off at a later date (Fig. 9 and 10a-b).

Three fresh inert (non-explosive) MK82 series bombs (500 lbs.) were observed on the sea floor in 2007 (Fig. 11a-b). These bombs were dropped either four or five days prior to that survey. The damage foot print from these inert bombs was approximately $17 \mathrm{~m}^{2}$ each. During the 2008 survey, the same sites were revisited. The bombs were gone and no broken coral or disturbed sea floor areas were seen; it was concluded that the ordnance items moved down slope into deeper water by natural forces and that that new algae, sponges and/or corals recruited to the disturbed areas making them indistinguishable from the adjacent sea floor. Any movement/rolling of the bombs down slope would be expected to damage 
or destroy sessile benthic organism in the bomb's path; however, the authors did not detect any evidence of such damage.

No blast pits or peels were observed in any of the surveys from 2005 to 2009 or in 2012. As used here, 'peels' are thin layers of rock removed or planed off the adjacent rock as distinguished from pits or craters. There was no clear evidence that any ordnance had detonated on or near the seafloor or at the sea surface during those six years.

The 2010 survey was conducted less than 55 hours after the most intense bombardment on record (up to that date) for FDM. Sea conditions were also the most benign ever experienced at FDM (Beauford Sea State 2 -4) during most of the six day survey (Fig. 3). It was clear that a small bomb or projectile had exploded at the waterline along a cliff ledge in Z1W. A newly exposed rock face measuring approximately $5 \mathrm{~m}$ in its maximum dimension parallel to the sea surface and approximately one $\mathrm{m}$ above and below the sea surface was observed. Fresh, white rock fragments were present below the newly exposed impact area, ranging in size from 2 to $30 \mathrm{~cm}$, and were observed at depths between 2 to $12 \mathrm{~m}$. No corals, or coral fragments were sighted. Sparsely distributed but apparently healthy corals were present on the cliff face within $3 \mathrm{~m}$ of the edge of the exposed rock. Most of these were Pocillopora sp. with maximum dimensions of less than $8 \mathrm{~cm}$. This genus includes many pioneering species. Apparent blast over-pressure mortality to small $(<10 \mathrm{~cm})$ oysters growing near the impact location was observed. The valves of 10 oysters were separated, with the top portion of several of the valves still lying beside the bottom/attached half of the oyster. These oyster shells would have been quickly washed away if normal wave conditions had been present and these impacts would not have been detected. No soft tissue remained in any of the oyster shells; presumably quickly consumed by fish or other sea creatures.

During the 2010 survey, a fresh crater/blast pit $5 \mathrm{~m}$ across and $50 \mathrm{~cm}$ deep was observed for the first time, located in the southern portion of Z3W, at a depth of $12 \mathrm{~m}$. This is likely to have been caused by a bomb detonation at the water surface. As with the previously described incident, this event occurred in an area dominated by relatively barren bedrock. No corals or any other sessile benthic invertebrates or the remains thereof were observed in the crater/blast pit or within a distance of $4 \mathrm{~m}$ from the edge of the crater. Past the $4 \mathrm{~m}$ perimeter (approximately $9 \mathrm{~m}$ from the center of the impact site), sea floor cover by corals was estimated to be less than $5 \%$; those corals did not show evidence of damage. Coral cover was uniform for most of Z3W ( $<5 \%-10 \%)$, except on the tops of some large cliff blocks and boulders where coral cover ranged to $>50 \%$. The bedrock segments of the sea floor with less than $5 \%$ coral cover are typical around much of FDM at depths of $14 \mathrm{~m}$ or less.

The 2010 survey probably provided the most accurate and worst case scenario for ordnance impacts on the physical and biological environment. About 1.2\% of the total items fired or dropped during the 2010 training event that preceded the 2010 survey were detected on the sea floor. 


\title{
3.2.2 Biological conditions
}

\begin{abstract}
Algae
Based upon total sea floor cover, crustose calcareous algae (CCA) and turf algae were the dominant functional algal groups from the intertidal zone to $30 \mathrm{~m}$. However, at depths below $15 \mathrm{~m}$ on the near vertical faces of large boulders, cliff blocks and sheer portions of the island's submerged walls, the calcareous green algae Halimeda sp. was very abundant and sometimes dominant. Sea floor cover by Cyanophyta/Cyanobacteria (Blue-green algae) was most abundant in 2007, consistent with the conclusions in PIFSC surveys (PIFSC 2008, 2014). No significant changes were observed between survey years for any of the other algal groups.
\end{abstract}

\section{Corals}

Scleractinia are the dominant coral group at FDM based upon the cover, frequency of occurrence, species diversity and influence upon other invertebrates and fishes. Of these, Pocillopora is the dominant genus; the two most abundant species during all survey years being Pocillopora meandrina and Pocillopora eydouxi. Massive growth forms of Porites (lobata and lutea) were the next most abundant based upon cover.

Well-developed coral reefs are present around many of the islands within the Mariana Archipelago. However, true coral reefs do not exist at FDM (Riegl et al. 2008). There is coral bearing substrate, but the corals are not sufficiently developed to be "...framework- or biogenic morphology-producing" (Riegl and Dodge 2008). The densest coral cover observed during all survey years was on the tops of large cliff blocks and bedrock spurs at depths of over $15 \mathrm{~m}$ (Fig. 7). A single exception to this can be found off the northern half of $\mathrm{Z} 2 \mathrm{~W}$ and southern portion of $\mathrm{Z} 3 \mathrm{~W}$. There, a relatively gentle sloping plateau extended from approximately 15 to $22 \mathrm{~m}$ deep and supported coral cover $>60 \%$, with much of that comprised of massive Porites sp. (Fig 12a\&b).

No significant changes in species composition, colony distribution, size frequency, COTS or predation by COTS, Black or White band diseases have been observed, and evidence of macro-bioeroders has been very limited. Excessive mucous production was never observed and an abundance of $0.5-2.0 \mathrm{~cm}$ sized corals (recruits) were present every year. Many authors have concluded that conditions such as these are indicative of healthy reef environments (Bruno et al. 2003; Cooper et al. 2008; Ghiold and Smith 1990; Hughes and Jackson 1980; Riegl 1995; Stafford-Smith 1993; Stafford-Smith and Ormond 1992; Sutherland et al. 2004 and Wild et al. 2005).

Two exceptions to this situation have been detected. The first occurred in 2007; a regional bleaching event extended from southern Japan through the Mariana Archipelago and south at least as far as the Republic of Palau. At FDM, members of the Scleractinia, Milleporina and Alcyonacea showed slight to severe bleaching. By the time of the 2008 survey, the Milleporina (fire corals) and Alcyonacea (soft corals), which had been bleached, appeared to have recovered completely. The authors estimated that $75 \%$ of bleached Scleractinia (primarily Pocillopora eydouxi or Pocillopora meandrina), had fully recovered by $2008 ; 25 \%$ died and were overgrown with CCA and/or other algae. 
The second significant event was an infestation of Pocillopora meandrina by the coral barnacle Cantellius sp. (Family Pyrgomatidae) in 2012. Approximately $40 \%$ of all the Pocillopora meandrina colonies were infested, dead or dying, including specimens at the northern end of FDM where no training activities take place. Comparative observations were made at two un-named reefs $2 \mathrm{~km}$ north of FDM. Pocillopora meandrina was the dominant coral at those locations. Although those reefs have never been subject to bombing, artillery fire or training of any kind, their infestation rate was estimated to be approximately double that observed at FDM. Therefore, it is unlikely that the infestation was related in any way to the Navy's activities. See Appendix 3 for additional information on this phenomenon.

Using frequency of occurrence and percentage cover, Alcyonacea rank second to Scleractinia. Lobophyton and Sinularia are most abundant at depths between 20 and $30 \mathrm{~m}$ in Z1W and Z4W. During the 2007 bleaching event, a number of specimens of both these genera located in Z1E and Z3E showed slight signs of bleaching $(<10 \%$ of the colony's surface area was bleached). The percentage of all soft corals showing some bleaching was estimated to be about $5 \%$ in 2007 . All the soft corals observed in 2008, 2009, 2010, and 2012 appeared to be healthy, including several colonies known to have been partially bleached in 2007. Cover by Sarcophyton sp. appeared to have increased in Z4W at the time of the 2010 survey and was continuing to increase in 2012. Areas which had previously been relatively bare bedrock supported numerous colonies.

Abundance estimates of all other coral groups were low during all survey years. Antipatheria (black and wire corals) were most often seen below $25 \mathrm{~m}$. Several black coral trees observed in Z1E and Z4W during 2005 were still present in 2012. Milleporina (fire corals) appeared to favor very large boulders and cliff blocks, some distance from the shoreline. Stylasterina (lace corals) and Gorgonacea (horny and whip corals and sea fans) were most common in the large sea caves and undercut ledges. No sea fans over $50 \mathrm{~cm}$ were seen. All the blue coral colonies (Helioporacea) were sighted at the north and south ends of the island.

\section{Fishes}

One or more representatives of 45 fish families were sighted during 2012 (see SI). Members of at least 42 families were seen each year. Fig. 13a-b and 14a-b illustrate some of these fishes. Representatives of some of the rarer families, for example, Ephippidae (spadefish), were only sighted in some years and they were never abundant ( $<5$ individuals per observation period). Most families whose members reached common or abundant levels varied little from year to year.

All of the fishes sighted appeared to be healthy and robust; no lesions or abnormalities were ever observed. All observations were consistent with previous literature and were what one would expect from a relatively isolated island in that biogeographic region. Specifically, the numerically dominant species at FDM closely matched the numerically dominant fishery target species in the Marianas Archipelago as reported by PFISC (2012) and Schroeder et al. (2006), and the location of the sightings and behavior matched descriptions of preferred habitat and activity patterns for these species as reported by Myers (1991), Randall $(2001,2007)$, and other investigators. For example, the twinspot snapper (Lutjanus bohar) was the most common large snapper and the sleek unicornfish (Naso hexacanthus) was the numerically dominant surgeonfish. 
For most of the fish taxa at FDM, the apparent slight variations noted year to year were probably random. There were three notable exceptions to this 'stable state'. During 2010 and particularly in 2012, changes were noted, which could be attributed to increased fishing pressure.

1) Large parrotfish, such as Scarus rubroviolaceus and Chlorurus frontalis were sighted in all zones between 2005 and 2009. Large specimens (> $45 \mathrm{~cm} \mathrm{TL}$ ) showed no fear of divers and could be easily approached. In 2010, fewer large specimens were sighted, and those sighted behaved in a skittish manner, quickly swimming away from the divers; a behavior characteristic of parrotfish in areas subject to spear fishing. In 2012, this situation was dramatically worse; that is, few large parrotfish of any species were observed in any zones and those which were sighted fled when approached.

2) The peacock grouper (Cephalopholis argus) and the lyretail grouper (Variola louti) were the most common groupers during the 2005 to 2010 surveys. Per Schroeder et al. (2006), this was an expected finding for the Marianas. Lyretail groupers were not sighted during the 2012 survey and fewer than ten peacock groupers were seen. Both these species are highly sought after by commercial spear fishermen.

3) Lutjanidae (snappers) includes some of the world's most popular food fish and many of its members in the Marianas are heavily fished. Lutjanids are one of the more abundant fish families at FDM. The twinspot snapper (Lutjanus bohar) was estimated to contribute more to fish biomass than any other snapper, grouper or emperor. This species was abundant during the 2005 to 2010 surveys (> 25 individuals counted / 20 minutes) in all Zones, except Z2E and Z2W. Aggregations of more than 100 individuals were sighted in 2007 in Z1W and Z4W. In 2008, aggregations were also sighted, but the number of individual fish was estimated to be less, $50-$ 75 individuals. No aggregations of the twinspot snapper were observed in 2009 and 2010, although schools of 10 to 15 individuals were sighted in all zones. In 2012, the largest number of twinspot snappers sighted during any dive was 20 and their total island wide numbers were estimated to be less than half of previous years. The usually bold and inquisitive twinspot snappers swam away when approached by divers in 2012. The humpback snapper (Lutjanus gibbus) was the second most common snapper during the 2006 to 2008 period followed by the bluelined snapper (Lutjanus kasmira). In 2009 and 2010, the bluelined snapper was judged to be more abundant than the humpback snapper. The 2009 and 2010 normalized counts for both species resulted in many more than 25 individuals counted in every zone meaning that these two snappers were abundant around the island. Counts of these two snapper species were not made during 2012. However, on six of the 19 dives, neither species was sighted. The total numbers of these three most common snapper species appear to have declined significantly between 2010 and 2012.

During biennial surveys (2000 - 2007) of coral reef shark populations performed around 50 U.S. Pacific islands, including the Mariana Archipelago, only five species of sharks were recorded in sufficient numbers for statistical analyses (Nadon et al. 2008): grey reef shark (Carcharhinus amblyrhynchos) (Fig. 13b), Galapagos shark (Carcharhinus galapagensis), whitetip reef shark (Triaenodon obesus), blacktip reef shark (Carcharhinus melanopterus), and tawny nurse shark (Nebrius ferrugineus). During all the authors' surveys of FDM the species positively identified were: the grey reef, blacktip reef, whitetip reef, and tawny nurse. No Galapagos sharks were positively identified although several sharks sighted were only identified to genus (Carcharhinus). No scalloped hammerheads or other hammerhead species have been sighted. Shark sightings are summarized in the SI section. Specimens greater than $300 \mathrm{~cm}$ TL (total length) were seen every year except 2007 and the number of shark sightings per diver averaged up to 3.7 per diver per dive. All shark species observed appeared to be healthy and stout. 
The spotted eagle ray (Aetobatis narinari) was the most common ray observed during all surveys. Schools of 25 spotted eagle rays were sighted off the southern tip of the island. Spotted eagle rays have been routinely observed in all zones around FDM and range in size from 100 to $200 \mathrm{~cm}$ in disc (wing) width. The black-blotched stingray (Taeniura meyeni) was the second most common ray sighted during the 2005 to 2012 time period. Like the spotted eagle ray, they have been observed in all zones. Four new distribution records for rays at FDM were made between 2005 and 2012. The Tahitian stingray (Himantura fai) was documented in 2010 in Z1W (Fig 13a). Two separate sightings of the porcupine ray (Urogymnus asperrimus synonymous with Urogymnus africanus) were made in 2007. The disc widths were approximately 90 and $125 \mathrm{~cm}$ for the specimens in Z2E and Z3E, respectively. A honeycomb stingray (Himantura uarnak), over $200 \mathrm{~cm}$ in disc width, was sighted in Z4E during the 2007 survey. Paulay (2003) does not list this species as being present in the Marianas although Myers (1991) records this species from Micronesia. The fourth new stingray record for FDM was the mangrove whipray (Himantura granulata). It was observed in Z2E in 2008.

Wrasses (Labridae) are one of the most speciose groups at FDM (DoN, 2005). This group includes the Napoleon wrasse (aka humphead wrasse Cheilinus undulatus). NOAA has listed this fish as a Species of Concern and the International Union for the Conservation of Nature (IUCN) Red List designates them as Endangered. Zgliezynski et al. (2008) conducted surveys for Napoleon wrasse at 32 U.S. flag Pacific islands, including islands in the Mariana Archipelago, but not at FDM. Zgliezynski et al. (2008) recorded the highest densities of this species at Wake Atoll. During the 2007 FDM survey, the numbers sighted were comparable to those reported at Wake Atoll. At FDM, juvenile, adult female, and adult male specimens (up to $200 \mathrm{~cm} \mathrm{TL}$ ) were observed each year and the number of sightings and locations at which sightings have been made increased with each survey, until 2010. The presence of Napoleon wrasse and their increasing numbers up to 2010 was considered highly significant, given the depressed numbers of this species in most of the archipelago and most of their global range. Fewer sightings were made in 2011. In 2012 only two mature Napoleon wrasse were sighted; TLs were estimated at 60 and $100 \mathrm{~cm}$, respectively.

\section{$\underline{\text { Sea turtles }}$}

The SI gives detail of the sea turtle sightings. Turtles were sighted during all 15 surveys, and appeared to be healthy. None of the specimens seen by the authors had any visible fibropapiloma tumors, barnacles, lesions, or other visible abnormalities.

The number of sea turtle sightings per biologist dive was low, ranging from 0.13 to 0.36 per biologist per dive in each year. For comparative purposes, some study sites off Oahu, Hawaii which have been surveyed since 1999 by the authors have averaged more than 10 sea turtles sighted per dive during all seasons; 28 times higher than the FDM densities. The precipitous sea cliffs, lack of suitable haul out sites or beaches preclude the ability of turtles to nest or bask at FDM. The authors believe that there are few, if any, year round resident sea turtles at FDM. Sea turtles are more likely transient visitors.

\subsection{Discussion}

\subsection{Physical environment}

Impacts, such as from ordnance that skipped or eroded off the island and rock and ordnance fragments blasted off the island, were detected every year. Direct impacts from inert ordnance was seen in four of 15 surveys. Evidence of in-water detonations was confirmed only twice between 1997 and 2012. The 
shoreline detonation and sea floor crater observed in 2010 resulted in approximately $10 \mathrm{~m}^{2}$ and $20 \mathrm{~m}^{2}$ of damaged rock/sea floor. The adjacent area of physical disturbance was estimated to be roughly $20 \mathrm{~m}^{2}$ and $110 \mathrm{~m}^{2}$. These impact areas were located in very high energy segments of FDM's coastline and natural coral cover at both sites was less than $5 \%$. These training related physical disturbances were therefore a relatively rare collateral effect of training and are insignificant compared to natural physical impacts or those from recreational divers and their dive vessels. Harriott (1997) documented the impacts of recreational divers and dive boat anchors and the authors have made similar assessments in the Caribbean, eastern, central and western Pacific, South China Sea and Indian Ocean. Typically, commercial and recreational dive boat anchors/lines/chain leave an impact footprint from 20 to $80 \mathrm{~m}^{2}$. The damage from a single cruise ship anchoring event in the Cayman Islands was 3,180 $\mathrm{m}^{2}$ (Smith 1988). Natural phenomenon, typhoons, tropical storms, large wave events, tsunamis/micro-tsunamis, and earthquakes are the primary determining factors which shape and modify FDM's physical environment between the intertidal zone and depths of $30 \mathrm{~m}$. Physical impacts from ordnance training were so few in number and most were so small in size that they were judged to have only short term, limited effects.

\subsection{Biological environment}

Over this 16 year period, no significant adverse long-term impacts to algae, corals, macroscopic benthic invertebrates, fishes or protected species have been detected that could be reasonably attributed to training at FDM. The observations of marine life are compatible with the findings reported for the 2003, 2005 and 2007 MRAMP of the other Mariana Islands (PIFSC 2014). However, there were four notable exceptions to patterns seen elsewhere in the archipelago:

1. Enhanced coral recovery from the 2007 bleaching event, compared to coral recovery in waters of the southern Mariana Islands

2. Near total absences of black band disease, white syndrome or growth anomalies among Scleractinia

3. The complete absence of the coral eating COTS during a period in which substantial numbers were recorded at the other Mariana Islands (PIFSC 2014) and no evidence of COTS predation

4. The higher abundance of selected fishery target invertebrates, such as sea cucumbers.

These are indicative of a healthy ecosystem. Daszak et al. (2000), Worm et al. (2006) and many other investigators have noted that coastal development and associated activities are having increasingly adverse impacts upon coastal marine resources. Non-consumptive recreational activities, like skin/SCUBA diving can have profound negative long-term adverse impacts on corals, coral reefs and associated marine resources; this fact has been well established by numerous investigators world-wide (e.g., Sudara and Nateekarnchanalap 1988; Harriott, Davies and Banks 1997; and Van Treech and Schumacher 1998). Consumptive recreational and commercial activities, primarily fishing and the collection of aquarium specimens, adversely impact corals/coral reefs as well as the species actually captured. Raymundo et al. (2009) demonstrated that functionally diverse and healthy reef-fish populations have significant beneficial effects on coral health.

Many anthropogenic stressors that have highly deleterious impacts on coral reefs and the associated flora and fauna are greatly reduced or completely absent at FDM (Table 4). 
FDM MPB ARTICLE VERSION APPROVED BY PACFLT

Table 4: Common coral reef stressors which are absent or reduced at FDM.

\begin{tabular}{|l|l|}
\hline \multicolumn{1}{|c|}{ Stressors } & \multicolumn{1}{c|}{ Stressors } \\
\hline Reef walking & Grounding of personal watercraft \\
\hline Skin /SCUBA Diving & Untreated sewage discharge personal watercraft \\
\hline Spear fishing & Improper/inadequate waste water disposal \\
\hline Trap \& net fishing & Improper/inadequate storm water runoff disposal \\
\hline Hook \& line fishing & Illegal dumping of hazardous materials/waste \\
\hline Jet skiing & Improper/inadequate erosion control \\
\hline Motorized personal watercraft & Harassment of marine life by beachgoers \\
\hline $\begin{array}{l}\text { Collection of corals \& invertebrates } \\
\text { for the aquarium trade }\end{array}$ & $\begin{array}{l}\text { Reduced H2O quality from large volumes of } \\
\text { sun block }\end{array}$ \\
\hline $\begin{array}{l}\text { Anchor damage from commercial } \\
\text { recreational \& private boaters \& } \\
\text { cruise ships \& cargo ships }\end{array}$ & $\begin{array}{l}\text { Improper disposal of refuse, particularly plastics, } \\
\text { diapers, pull tabs, bottle caps and cans }\end{array}$ \\
\hline
\end{tabular}

From 1997 - 2009, the bony fish population was stable and fish behavior was unchanged. Even highly prized fishery target species closely associated with the island (e.g. parrotfishes, groupers and sweetlips) showed neutral or inquisitive behavior towards the divers. The coral recovery from the 2007 bleaching event was undoubtedly aided by an abundant population of herbivorous fishes (Sheppard 1999, Smith 1999, Smith and Marx 2010, PIFSC 2014). The absence of COTS may be due to the presence of large mature Napoleon wrasse (Cheilinus undulatus), which are one of the few known predators of COTS. During the 2010 survey, the numbers of certain sought after species was lower and they were more wary of divers. This 'flight-type behavior' became increasingly more pronounced in 2012 and is indicative of fishes subject to spear fishing pressure. Crew of Saipan Crew Boats that provided the liveaboard vessel support from 2006 through 2012 reported to the authors that commercial spear fishermen had begun to visit FDM as well as hook and line fishermen. During the 2010 survey, three separate fishing boats were sighted at FDM, two of which anchored and remained over-night. The small size of FDM makes it very vulnerable to overfishing, particularly spear fishing.

In spite of the apparent increased fishing pressure, FDM fish stocks in 2012 were still estimated to be substantially greater both in numbers of fish and larger individuals than those around any of the inhabited Mariana Islands to the south. In Pearl Harbor, the Navy's restricted access policy was shown to result in more abundant fishes and larger individual specimens (Smith, Deslarzes and Brock 2006). Like Pearl Harbor, the Navy's limited access policy at FDM has produced a de-facto MPA effect. The distance of FDM from inhabited islands and its exposed nature also afford it some protection.

The rate of shark sightings can be indicative of a healthy ecosystem (Graham et al. 2010). Shark sightings at FDM were superior even to those recorded in the Chagos Archipelago (which supports the central Indian Ocean's most abundant shark population). Graham et al. (2010) reported that the mean per scientific dive in 2006 in the Chagos Archipelago was 0.4; at FDM in 2006 it was 1.27 and in 2010 and 2012 it was 3.7 and 2.0 , respectively. 
Sea turtles have been sighted in roughly comparable numbers during every survey between 1999 and 2012, which is much lower than, for example, Oahu, Hawaii where it was $>10$ sightings/observation period for the 1999 - 2014 time period. There are no suitable nesting beaches on FDM. No sea turtle remains, such as carapace or bone fragments, have ever been sighted or reported at FDM. The authors have encountered such remains at various locations in the Bahamas, Cayman Islands, Hawaiian Islands and Malaysia, which support resident sea turtle populations. Sea turtles around FDM probably represent transient individuals and not a resident population.

\subsection{Conclusions}

There was no evidence that any of the biological resources assessed had been adversely impacted to a significant degree by the training activities being conducted at FDM between 1997 and 2012. Instead, the benefits of restricted access to FDM have resulted in a de-facto preserve effect and outweigh what are minor negative impacts of training. Marine natural resources assessed at FDM are comparable to or superior to those at other locations within the Mariana Archipelago. This suggests that the greatest threat to FDM's marine resources is from fishermen, not military training activities. The large numbers and large sizes of fishes at FDM are well known to many. In The State of Coral Reef Ecosystems of Guam (Burdick et al. 2008), overfishing and water pollution are listed among the most serious threats to the marine environment. FDM has been free and will remain free of the latter, but has become more vulnerable to the former.

\section{Acknowledgements}

We wish to thank U.S. Navy Pacific Fleet Environmental Readiness Division for providing the funding to conduct the scientific dive surveys as well as the preparation of the publication. 
Figure 1. Mariana Archipelago

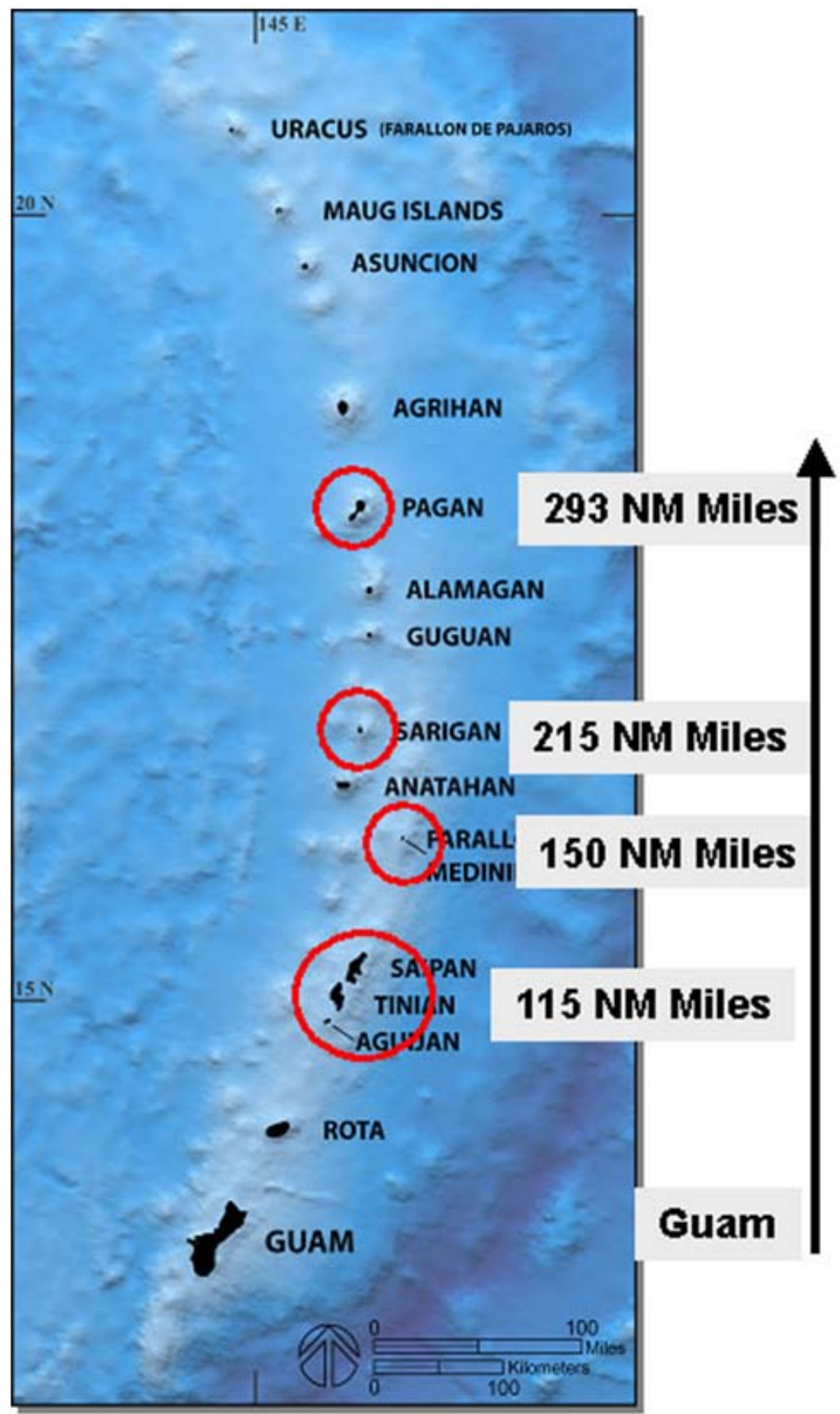


Figure 2. Farallon De Medinilla viewed from the south with common sea conditions.

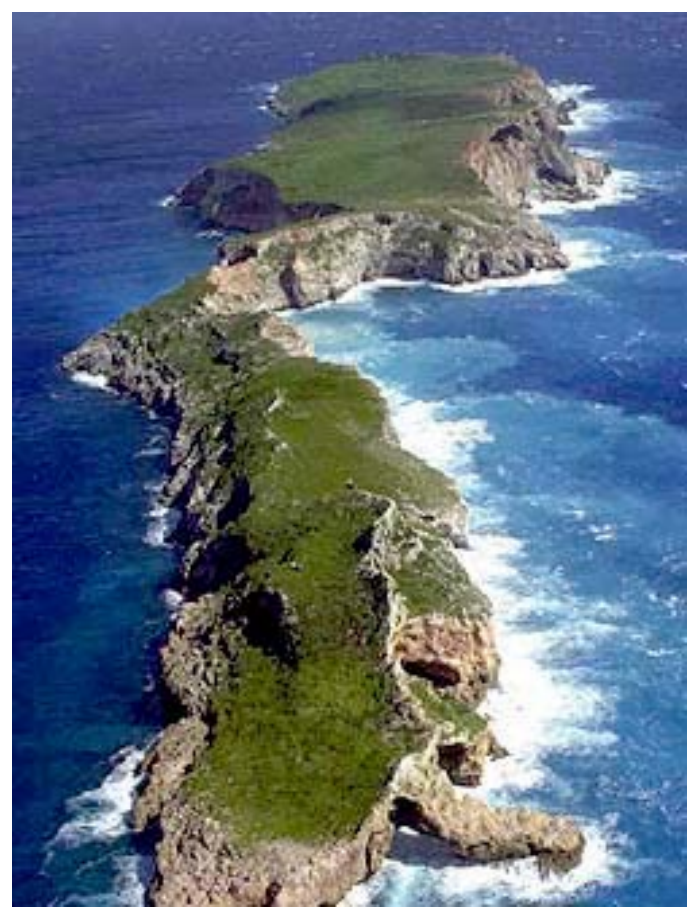

Figure 3. Farallon De Medinilla, NW coast showing unstable sea cliffs and caves. Large, extensive submarine caves are present around the island. Photo taken in 2010 during calmest sea state ever encountered.

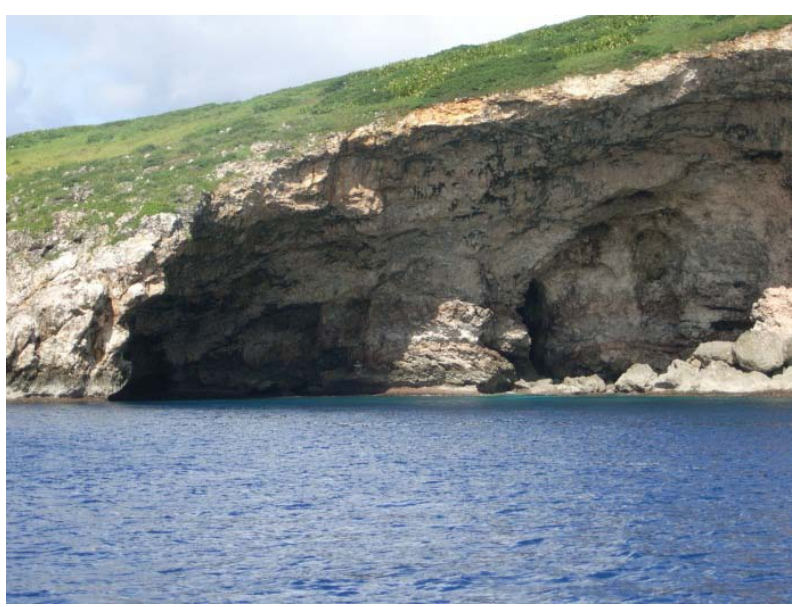


Figure 4. Typhoon and tropical storm tracks in the vicinity of Farallon De Medinilla 1995 to 2012.

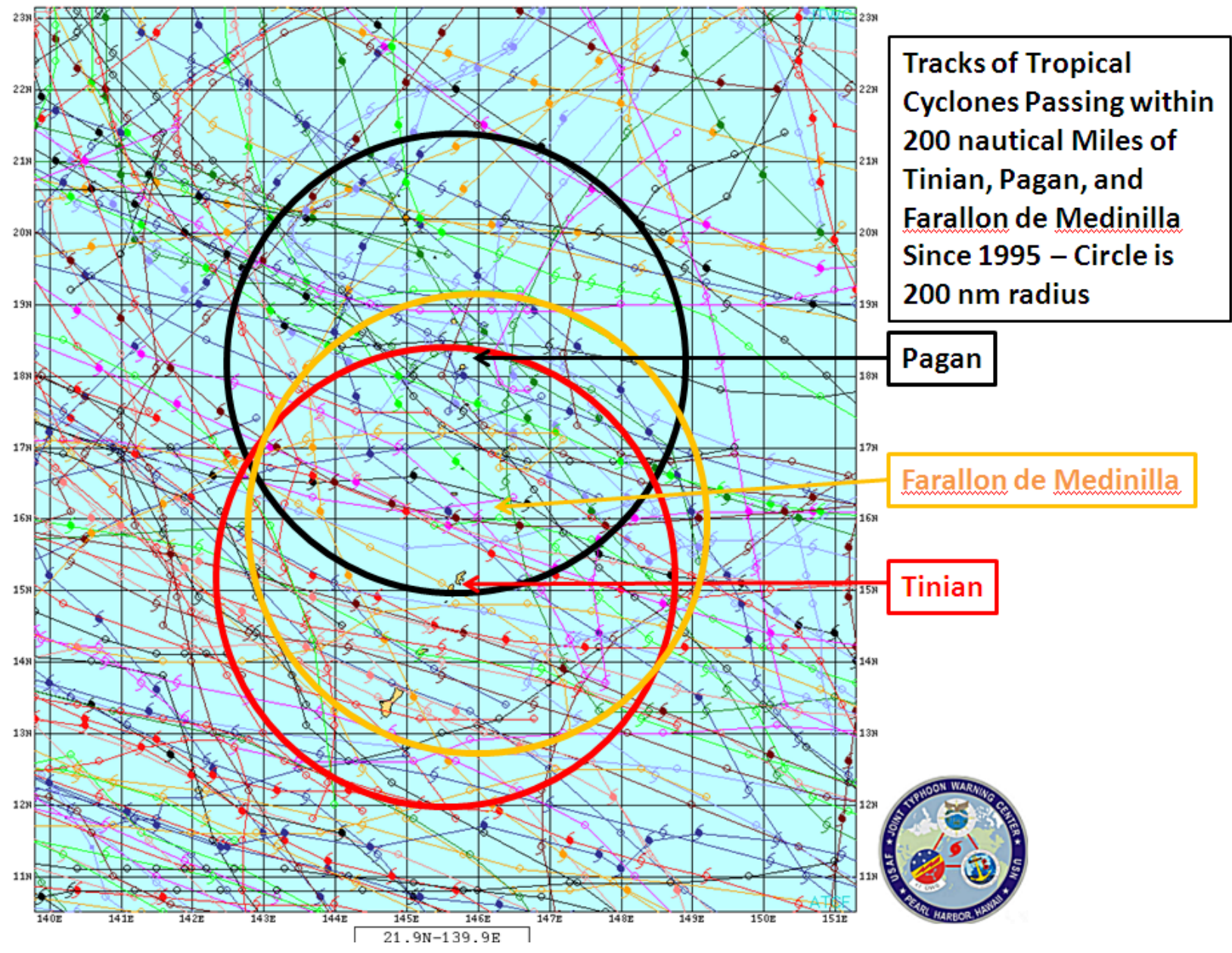


Figure 5. Training Zones at Farallon De Medinilla and the dive survey tracks completed in 2012. Note, nearly identical tracks were completed during all surveys since 2005.

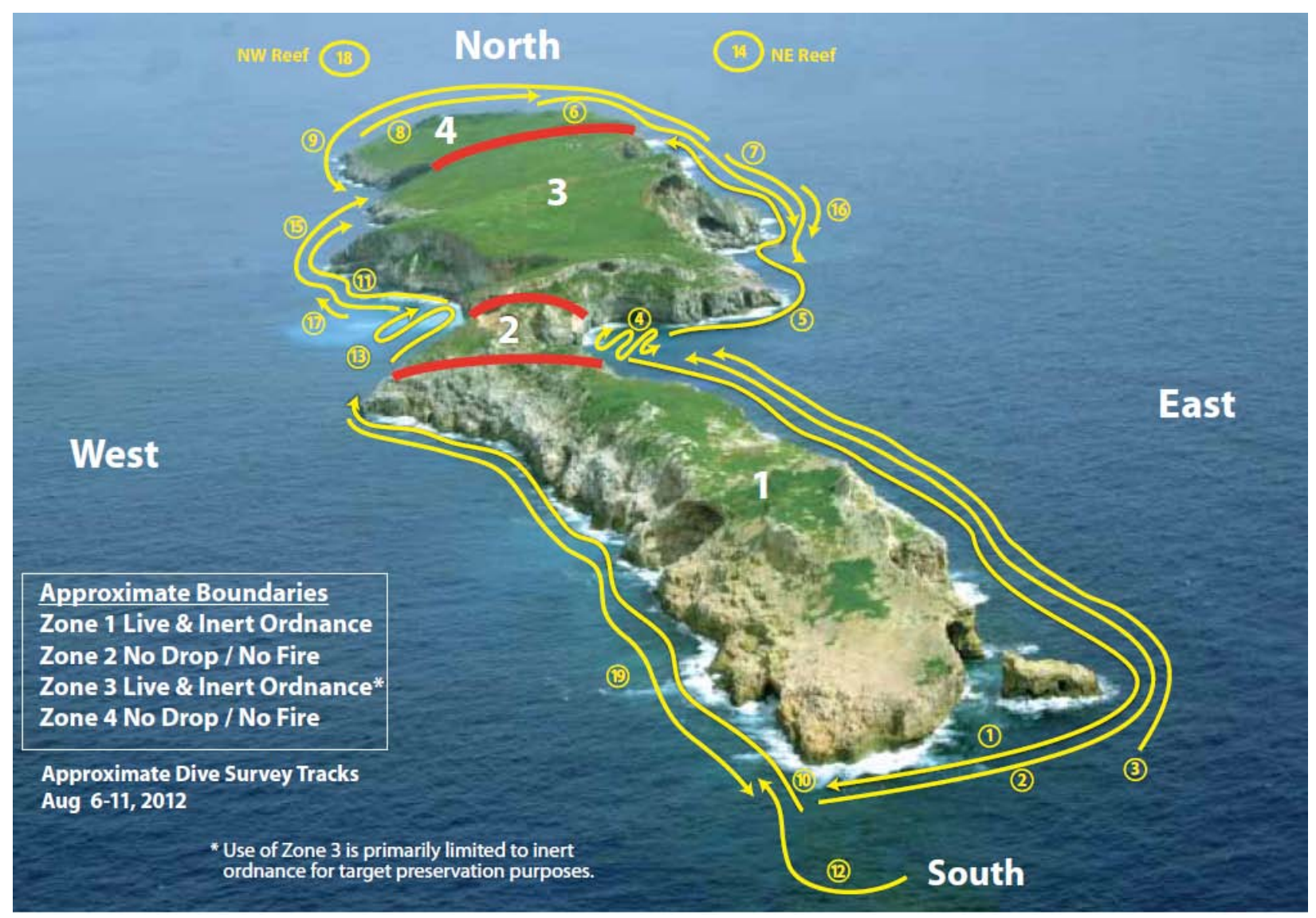


Figure 6. Coarse sand, with boulders and small cliff blocks, depth 15 m Z4E.

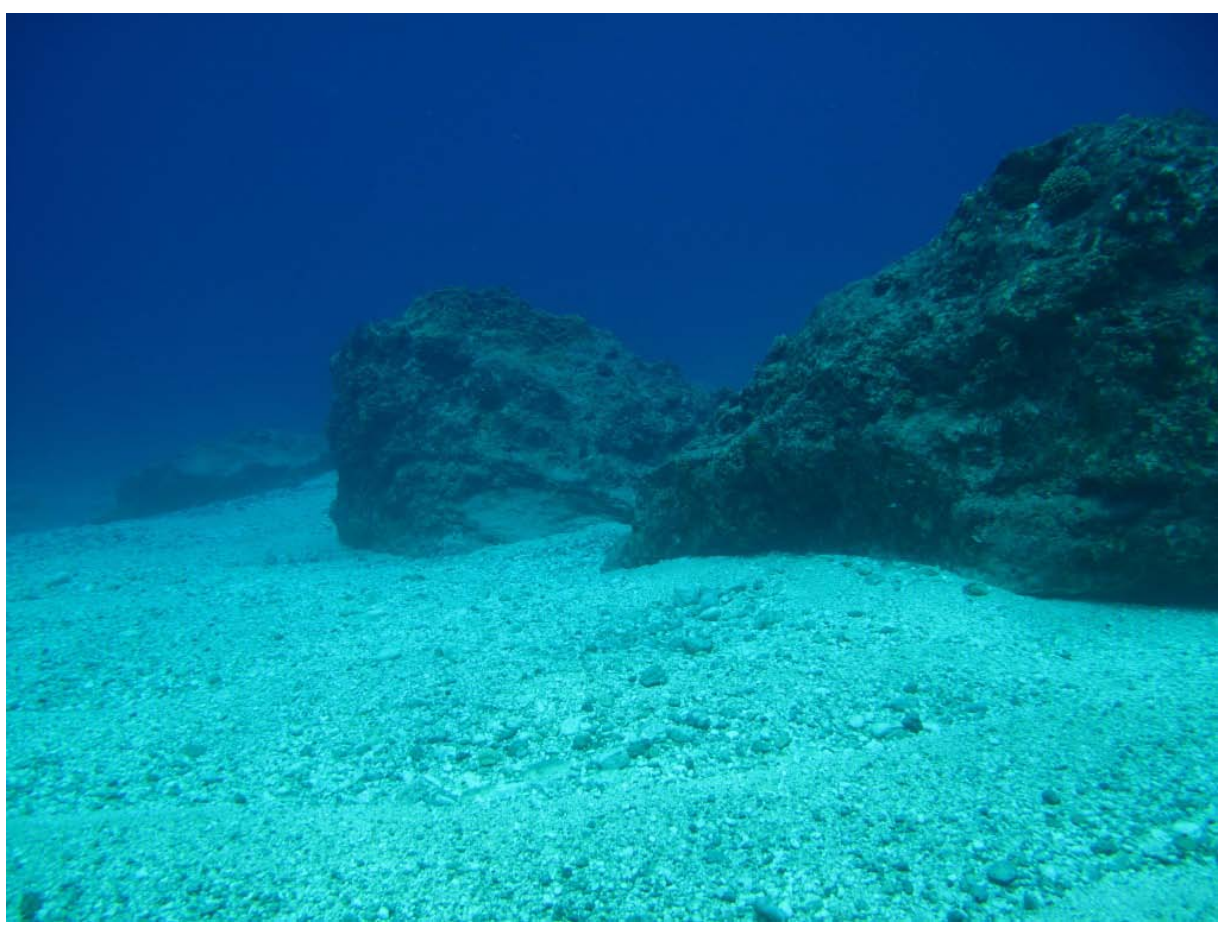

Figure 7. Cliff block at $18 \mathrm{~m}$ with extensive coral cover Z4W. Note, scour, exposed bedrock and small boulders at base of cliff block.

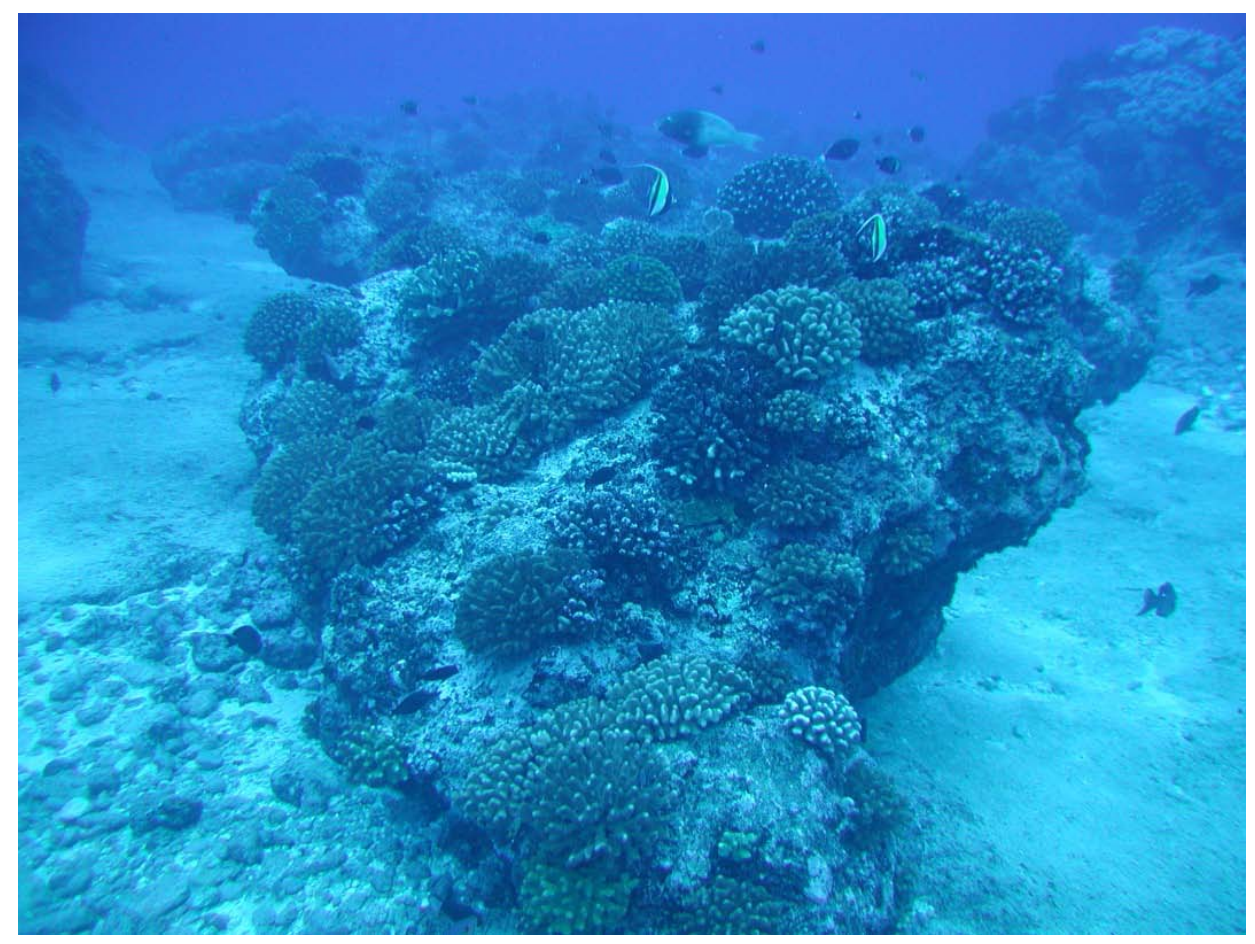


Figure 8. Typical cliff face exposed to high energy wave regime Z1W $12 \mathrm{~m}$ depth.

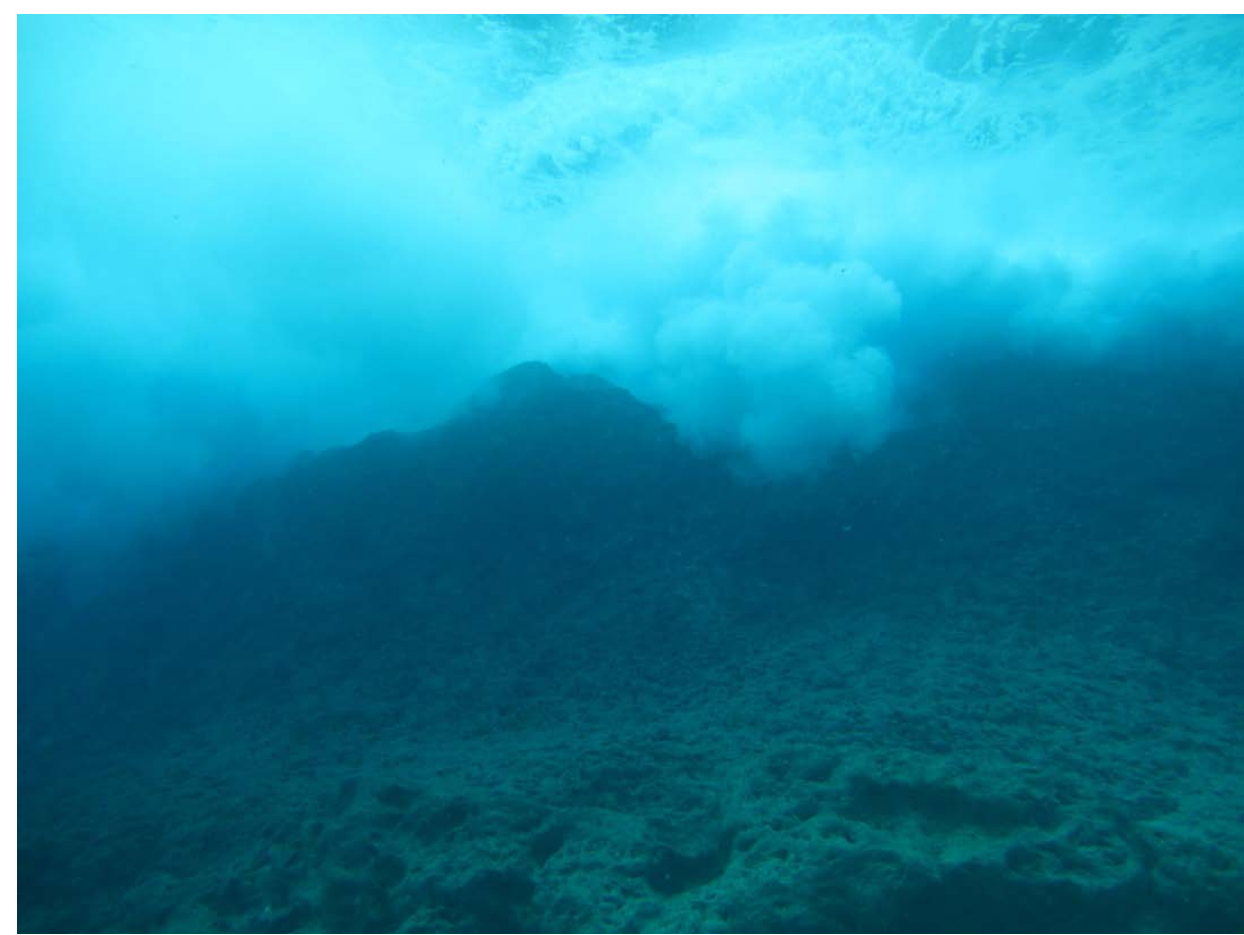

Figure 9. Inert MK 82 bomb severely bent as a result of hitting the island then ricocheting into the sea. This bomb had been dropped either 4 or 5 days prior to the photo being taken. Note coarse sand and boulders and exposed bedrock.

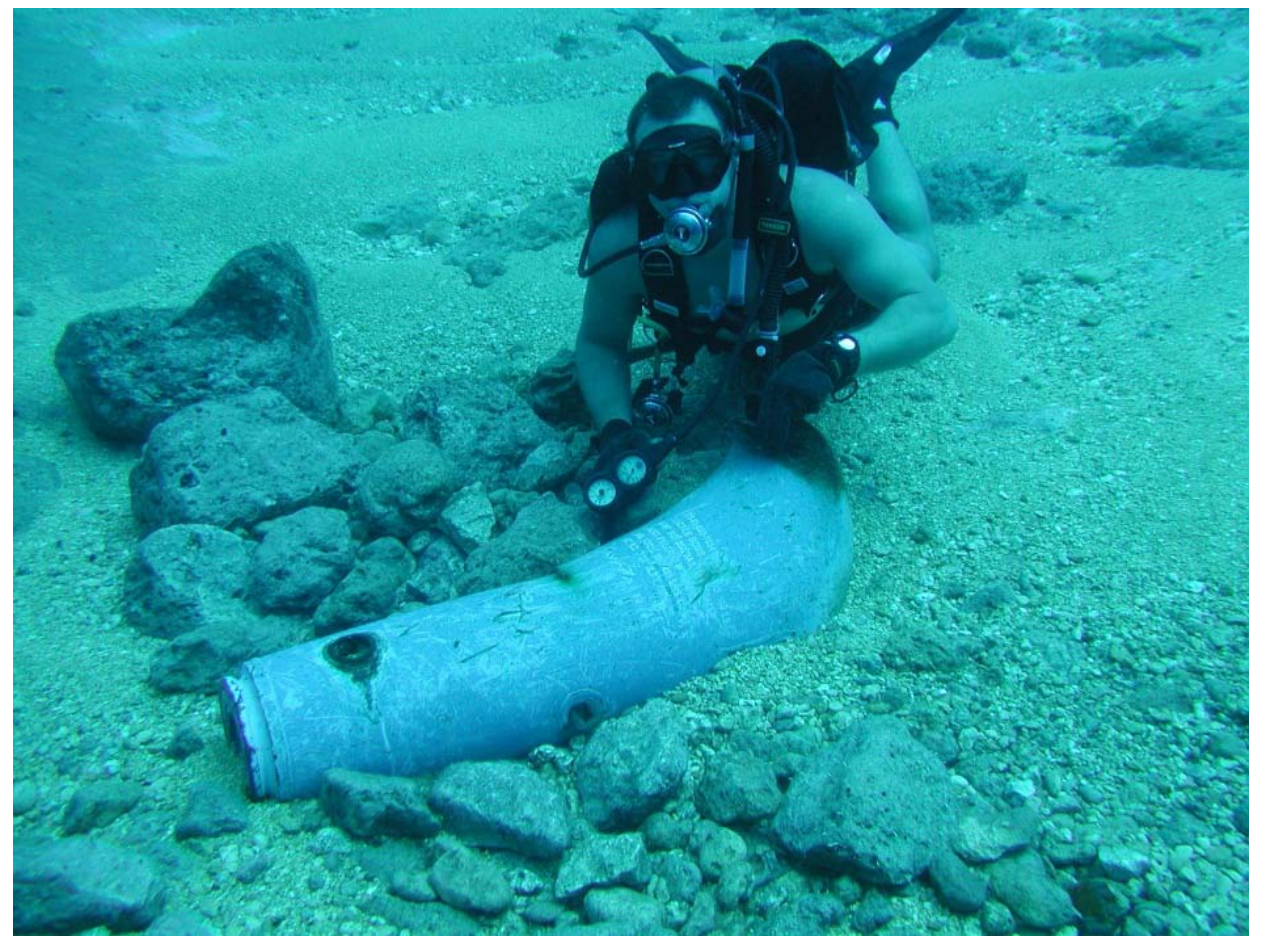


Figure 10a. Top: Inert 25 LB practice bomb, judged to have bounced of island. Figure 10b. Bottom: Rocket fragment.
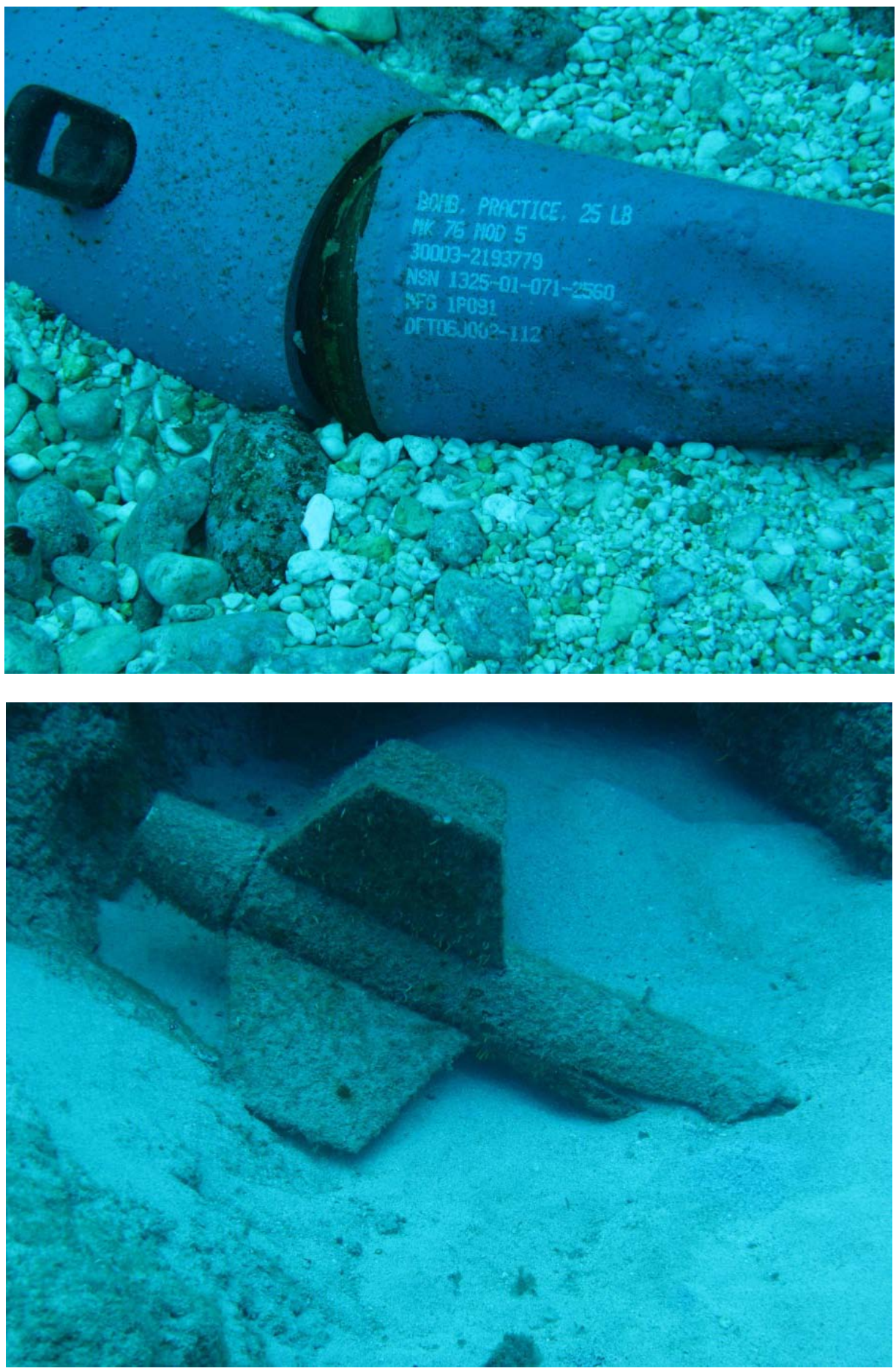
Figure 11a. MK 82 inert bomb (168 cm long) which directly impacted the sea floor @ a depth of $12 \mathrm{~m}$ in Z3E on 5 or 6 September 2007; photographed on 13 September 2007. Area of destruction/disturbance was approximately $17 \mathrm{~m}^{2}$. Figure 11b. Below, MK 82 bombs with Pocilloporid corals, algae, etc.
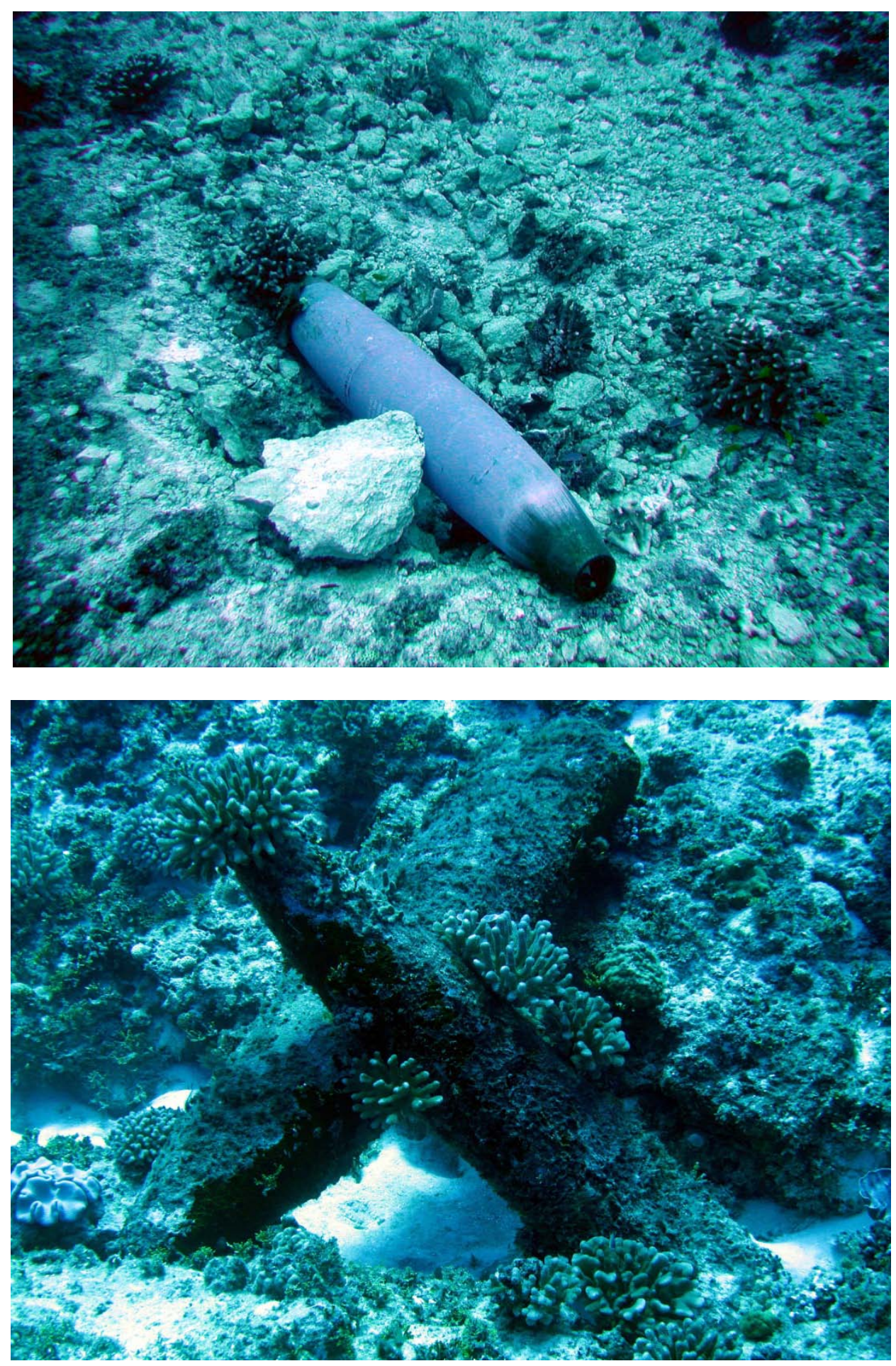
Figure $12 a \& b$. The 15-22 $m$ deep plateau in portions of Z2W and Z3W supports the largest and most extensive Scleractian coral cover on FDM.
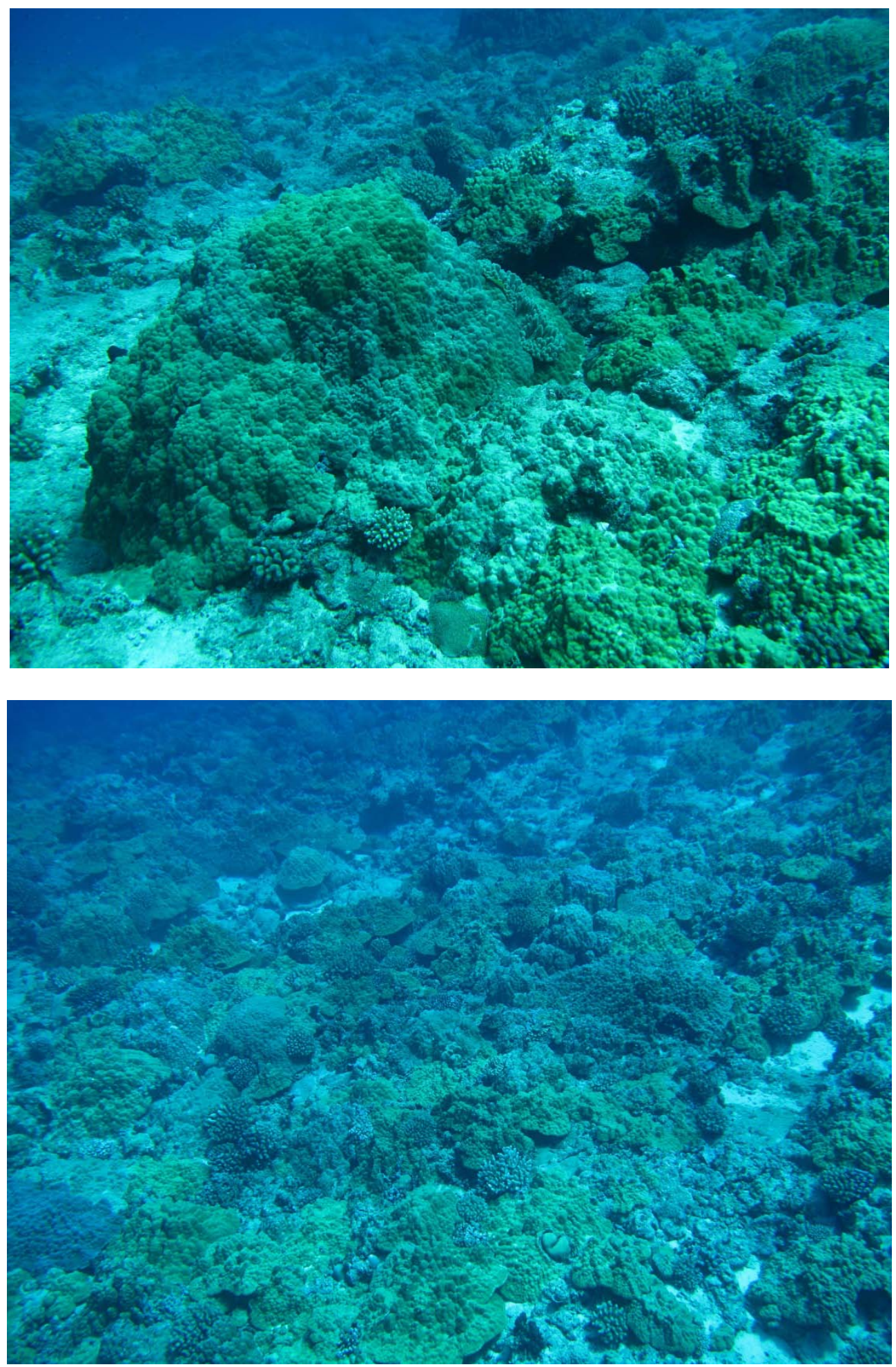
Figure 13a Tahitian stingray (Himantura fai), a new distribution record. Figure 13b Below, Grey reef shark Carcharhinus amblyrhynchos.
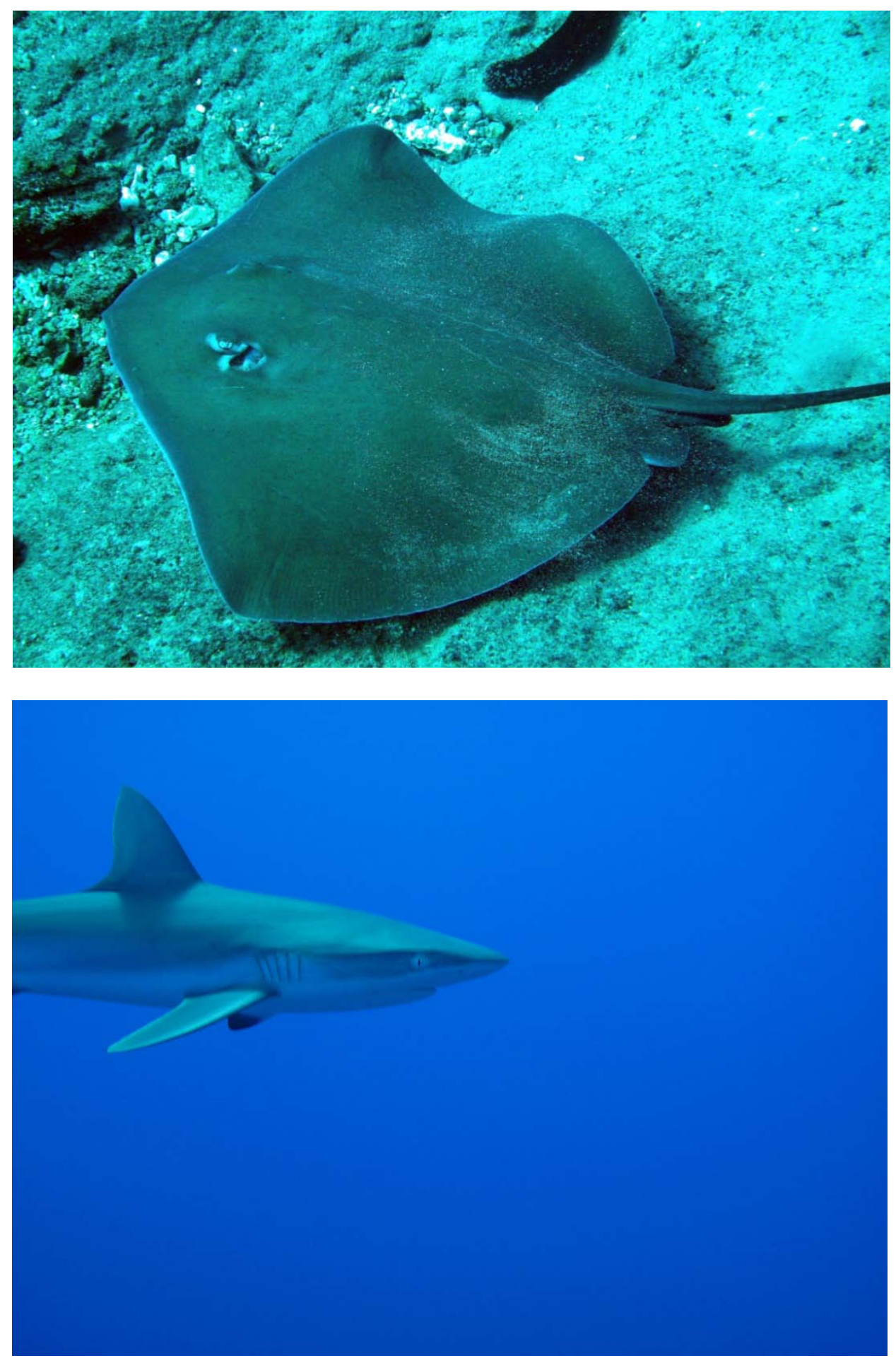
Figure 14a. Top - Black/sleek unicornfish (Naso hexacanthus) and yellowback fusiliers (Caseo teres), and Figure 14b (bottom) bigeye trevally (Caranx sexfasciatus) are among FDM most abundant fishes.
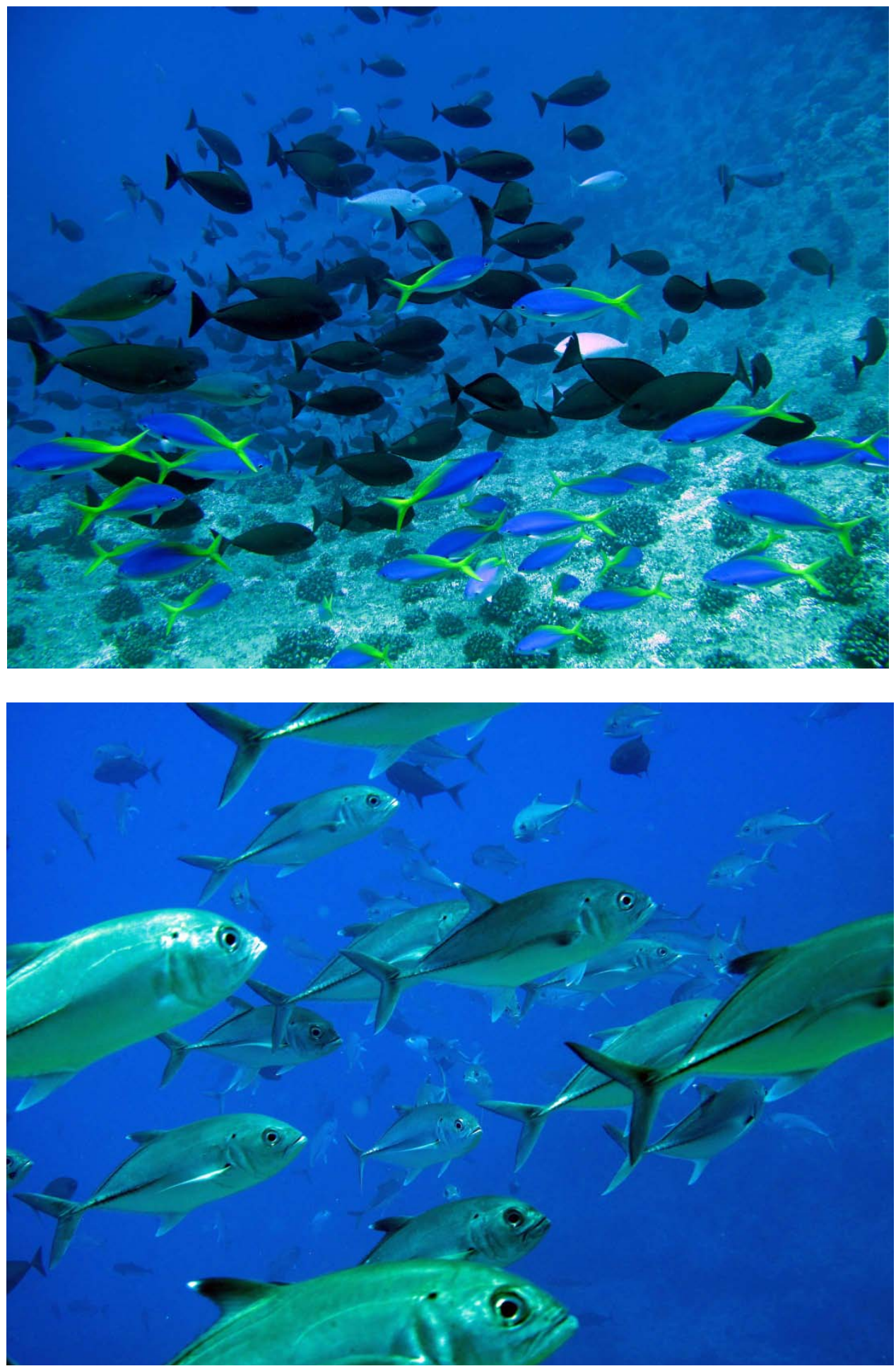


\section{APPENDIX 1.}

\section{Summary of survey methods used during the $1997-2004$ surveys.}

These surveys were conducted by the same four biologists each year. There was one representative of the University of Hawaii, one from NOAA, and one from USFWS and one from the Government of the CNMI. Each survey began with a low altitude helicopter aerial reconnaissance. Investigators were then towed behind inflatable boats (snorkeling) and circumnavigated the island using a Rapid Ecological Assessment (REA) approach to evaluating the marine community. These tows provided information on overall habitat type and community assemblages. Most importantly, the tows were intended to identify underwater damage that could have been the result of military training. Lastly, scuba dives were made at selected locations which the investigators deemed to warrant closer inspection. Investigators were prohibited from touching the seafloor, so no benthic transects or quadrats were utilized. Instead, point to point swims were completed while the investigators evaluated the health and abundance of selected organisms. Maximum dive depths were $18 \mathrm{~m}$ and dive times were 30 minutes. Species lists, based upon field identifications, were made during each survey for corals, selected invertebrates, and fishes. Relative abundance, per 30 minute observation period, was evaluated using the following criteria: abundant ( $>25$ individuals), common (15-25), uncommon $(5<15)$, and rare $(<5)$. During most of the survey years, each biologist completed six dives for a total of 24 'biological dives' per survey. 


\section{APPENDIX 2}

\section{Discussion of possible ordnance impacts observed during 2004 survey.}

The four biologists that performed the investigations during this time period unanimously agreed that the physical environment, flora, and fauna assessed were unchanged from 1997 through 2003 . They determined there were no serious impacts from exploded ordnance and the pieces of unexploded ordnance did not appear to cause any negative effects to any of the marine resources assessed. Ordnance items were often the site of settlement of a variety of marine organisms (U.S. Government 2004). There were examples of fresh terrigenous debris on the sea floor, but the investigators concluded that none of the terrestrial items sighted between 1999 and 2003 had caused significant adverse impacts to the marine environment. No significant changes in species composition, diversity or health were detected. During the 2004 survey, areas of freshly peeled rock (several $\mathrm{m}^{2}$ ), broken coral and fresh boulders were observed on the sea floor. The freshly peeled rock and broken corals were bare and free from any marine growth; some of the boulders still had terrestrial grasses on them. It was clear then, that these items had only been exposed, or in the sea for a very brief time. During 2004, military training at FDM was more intense than it had been since 1999. That training took place between January and May 2004. The 2004 survey took place July 12-15, 2004. Typhoon Tingting (a category 1 typhoon) passed directly over FDM on June 28, 2004. After detailed analysis and discussion, the report made the following conclusion: "Although some damage can be directly attributed to ordnance impacts, natural factors also contribute to the changes. Examination of photographs from 1944 indicate that changes in the geologic structure of the island by erosion and mass wasting ...have been going on for decades....With respect to damage associated with the passage of Typhoon Ting Ting...it is clear that the breakage of some coral branches is a result of the concussive force of large waves.... These factors suggest that the breakage was the result of storm surf..." (DoN 2005). 


\section{APPENDIX 3}

Infestation by the coral barnacle Cantellius sp. 2012

At the time of the 2012 survey, approximately $40 \%$ of all the Pocillopora meandrina colonies were dead or dying, as explained below. The $40 \%$ estimate was derived based upon: 1 ) the analysis of 100 photos taken at random around FDM, 2) Smith's qualitative estimate, and 3) limited LPI transect data. Comparative dives were made at two submerged reefs approximately $2 \mathrm{~km}$ north of FDM. Those reefs have never been subjected to Navy training activities. Like FDM, Pocillopora meandrina was the dominant coral at those locations. Based upon photo analysis and Smith's qualitative estimate, approximately 65 to $75 \%$ of the Pocillopora meandrina colonies at the un-named reef locations were dead or dying. The affected Pocillopora meandrina colonies appeared to be undergoing a three-phase "disease process".

- First, the colonies were severely infested with blister like formations caused by the coral barnacle (Family Pyrgomatidae - Genus Cantellius).

- Second, coral colonies with numerous barnacles on all of their branches took on a bleached appearance; presumable due to the loss/expulsion of their zooxanthellae.

- Third, the bleached coral colonies were overgrown with Cyanobacteria, followed by other algal groups. Based on the physical condition of the colonies and algal communities on their skeletons, most of the deceased specimens appeared to have been dead for six to 12 months.

Generic and tentative species (C. pallidus) identification of the barnacle was provided by G. Paulay and M. Malay (personal communication, 2012), based upon photos. The Cantellius group of coral barnacles is known to be very host specific to Pocillopora meandrina and closely related corals and has been previously collected off the Zealandia Bank in the Mariana Archipelago (Malay personnel communication 2012). While hundreds of Pocillopora meandrina colonies were infested with Cantellius $s p$., only one colony of Acropora sp. and seven colonies of Pocillopora eydouxi were sighted with any Cantellius $s p$. barnacles. All eight of those colonies were judged to be 'holding their own' against the barnacles. Cantellius barnacles are a large, taxonomically complex group, members of which also infest the coral genera Acropora, Montipora and Porites (Malay personal communication 2012). Although those three genera are well represented at FDM, only a single colony of Acropora was infested. Cantellius sp. barnacles found on Pocillopora $s p$. are usually rare, and cryptic, and only found on the lower or inner branches of the coral colonies. At FDM in 2012, over $90 \%$ of the infested colonies were covered with the barnacles all the way out to the tips of the branches. 


\section{REFERENCES}

[1] Bruno, J. F. et al. 2003. Nutrient enrichment can increase the severity of coral disease. Ecol. Lett. 6, 1056-1061.

[2] Burdick, D. et al. 2008. The state of coral reef ecosystems of Guam, in: The State of Coral Reef Ecosystems of the United States and Pacific Freely Associated States: National Oceanic and Atmospheric Administration in Cooperation with Partners from Federal, Territorial and Commonwealth Agencies and the Pacific Freely Associated States. pp. 465-509.

[3] Carpenter, K.E. et al. 2008. One third of reef-building corals face elevated extinction risk from climate change and local impacts. Science 321, 560-563.

[4] Connell, S.D., Foster M.S., Airoldi L. 2014. What are algal turfs? Towards a better description. Mar. Ecol. Prog. Ser. 495, 299-307.

[5] Cooper, T. F. et al. 2008. Temporal dynamics in coral bioindicators for water quality on coastal reefs of the Great Barrier Reef. Mar. Freshw. Res. 59, 703-716.

[6] Daszak, P. et al. 2000. Emerging infectious diseases of wildlife - threats to biodiversity and human health. Science 287, 443-449.

[7] Friedlander, A.M. et al. 2014. Coexistence of low coral cover and high fish biomass at Farquhar Atoll, Seychelles. PLOS ONE 9:1, 11.

[8] Ghiold, J., Smith, S. H. 1990. Bleaching and recovery of deep-water, reef-dwelling invertebrates in the Cayman Islands, B.W.I. Caribbean J. Sci. 26:1-2, 52-61.

[9] Halpern, B. S. 2003. The impact of marine reserves: do reserves work and does reserve size matter? Ecol. Appl. 13, 117-137.

[10] Harriott, V. J. 1997. Recreational diving and its impacts in marine protected areas in eastern Australia. Ambio. 26, 173-179.

[11] Hughes, T. P., Jackson, J.B.C. 1980. Do corals lie about their age? Some demographic consequences of partial mortality, fission and fusion. Science 209, 713-715.

[12] Jackson, J.B.C. et al. 2001. Historical overfishing and the recent collapse of coastal ecosystems. Science 293, 629-636.

[13] Kerwath, S.E. et al. 2008. Crossing invisible boundaries: the effectiveness of the Langebaan Lagoon Marine Protected Area as a harvest refuge for migratory fish species in South Africa.

Conserv. Biol. 23:3, 653-661.

[14] Littler, D. S., Littler, M. M. 2003. South Pacific Reef Plants. A Diver's Guide to the Plant Life of South Pacific Coral Reefs. Washington, D.C.

[15] Malay, M. 2012. Personal communication between Stephen H. Smith, NAVFAC EXWC and Machel Malay, Florida Museum of Natural History. 
[16] Mydlarz, L. D. et al. 2006. Innate immunity, environmental drivers, and disease ecology of marine and freshwater invertebrates. Annu. Rev. Ecol. Syst. 37, 251-288.

[17] Myers, R. F. 1991. Micronesian Reef Fishes, Second Ed., Barrigada, Guam.

[18] Nadon M. et al. 2008. Central pacific survey reveals lower shark density near human population centers. Proc. 11th Int. Coral Reef Symposium 194, 22-48.

[19] Nicholas, A.J., Graham, J., Spalding, M.D., Sheppard, C.R.C. 2010. Reef shark declines in remote atolls highlight the need for multi-faceted conservation action. Aquat. Conserv. 20, 543-548.

[20] Porter, V. et al. 2005. Status of the coral reef ecosystems of Guam. University of Guam Marine Laboratory Technical Report No. 113.

[21] Randall, J. E. 2001. Surgeonfishes of Hawaii and the world. Honolulu, HI.

[22] Randal, J. E. 2007. Reef and shore fishes of the Hawaiian Islands. Honolulu, HI: Sea Grant College Program, School of Ocean and Earth Science and Technology, University of Hawai i.

[23] Randall, R. H. 2003. An annotated checklist of hydrozoan and scleractinian corals collected from Guam and other Mariana Islands. Micronesica 35-36, 121-137.

[24] Randall, R. H., Eldredge, L. 1977. Effects of typhoon Pamela on the coral reefs of Guam. Proc. 3rd Int. Coral Reef Symposium 2, 526-531.

[25] Raymundo, L. J. et al. 2009. Functionally diverse reef-fish communities ameliorate coral disease. PNAS 106, 17070-17076.

[26] Richmond R. H. et al. 2008. Chapter 19: Aspects of biology and ecological functioning of coral reefs in Guam and the Commonwealth of the Northern Mariana Islands, in: Riegl, B.M., Dodge, R.E. (Eds.), Coral Reefs of the World 1: Coral Reefs of the USA. Springer Science + Business Media \#1, pp. 719-739.

[27] Riegl B. M. 1995. Effects of sand deposition on Scleractinian and Alcyonacean corals. Mar. Biol.121, 517-526.

[28] Riegl B. M. et al. 2008. Chapter 18: Geologic setting and geomorphology of coral reefs in the Mariana Islands (Guam and Commonwealth of the Northern Mariana Islands), in: Riegl, B.M., Dodge, R.E. (Eds.), Coral Reefs of the World 1: Coral Reefs of the USA. Springer Science + Business Media \#1, pp. 691-718.

[29] Roberts C. M. et al. 2001. Effects of marine reserves on adjacent fisheries. Science 294, 19201923.

[30] Schroeder R.E. et al. 2006. Status of fishery target species on coral reefs of the Mariana archipelago. Proc. 10th Int. Coral Reef Symposium, 1016-1027.

[31] Selig, E. R., Bruno, J. F. 2010. A global analysis of the effectiveness of marine protected areas in preventing coral loss. PLOS ONE 5:2, 1-7. 
[32] Sheppard, C.R.C. et al. 2012. Reefs and islands of the Chagos Archipelago, Indian Ocean: why it is the world's largest no-take marine protected area. Aquat. Conserv. 22:2, 232-261.

[33] Shivlani, M. 2007. A literature review of sources and effects of non-extractive stressors to coral reef ecosystems, in: Final Report PO\# DO320248 for The Southeast Florida Coral Reef Initiative and Florida Department of Environmental Protection, pp. 1-18.

[33] Smith, S.H. 1988. Cruise ships: a serious threat to coral reefs and associated organisms. Ocean \& Shoreline Management 11, 231-248.

[34] Smith S.H., Deslarzes, K.J.P., Brock, R. 2006. Characterization of fish and benthic communities of Pearl Harbor and Pearl Harbor Entrance Channel Hawaii. Department of Defense Legacy Resource Management Program, Project No. 03-183, pp. 1-73.

[35] Spalding, M. D., et al. 2001. World Atlas of Coral Reefs. Berkeley, California.

[36] Stafford-Smith, M.G. 1993. Sediment rejection mechanisms of 22 species of Australian scleractinian corals. Mar Biol 115, 229-243.

[37] Stafford-Smith, M. G., Ormond, R. F. G. 1992. Sediment rejection mechanisms of 42 species of Australian scleractinian corals. Aust J Mar Freshw Res 43, 683-705.

[38] Stein, B. A. 2008. Biodiversity and the military mission, in: Benton, N., Ripley, D., Powledge, F. (Eds.), Conserving Biodiversity on Military Lands: A Guide for Natural Resources Managers. NatureServe, Arlington, VA.

[39] Sudara, S., Nateekarnchanalap, S. 1988. Impact of tourism development on the reefs of Thailand. Proc. 6th Int. Coral Reef Symposium 2, 273- 278.

[40] Sutherland, K. P., et al. 2004. Disease and immunity in Caribbean and Indo-Pacific zooxanthellate corals. Mar Ecol Prog Ser 266, 273-302.

[41] U. S. Government. 1998. National Marine Fisheries Service. Endangered Species Act Section 7 Consultation, Biological Opinion -Use of the Farallon De Medinilla live fire range by the U.S. Navy and other services.

[42] U. S. Government. 1999. Department of the Navy. Prepared for the U.S. Pacific Command, Pearl Harbor, Hawaii by Belt Collins, Hawaii. Final Environmental Impact Statement; Military training in the Marianas. Honolulu, Hawaii.

[43] U. S. Government. 1999a. Department of the Navy. Prepared for the U.S. Pacific Command, Pearl Harbor, Hawaii by Belt Collins Hawaii. Botanical Survey of Farallon De Medinilla, CNMI in Final Environmental Impact Statement: Military Training in the Marianas. Honolulu, Hawaii.

[44] U. S. Government. 2005. Department of the Navy. Prepared for the U.S. Pacific Command, Pearl Harbor, Hawaii by TEC. Year 2004 Assessment of the Marine and Fisheries Resources Farallon de Medinilla, Commonwealth of the Northern Mariana Islands. Honolulu, Hawaii.

[45] U.S. Government. 2008. NOAA Pacific Islands Fisheries Science Center (PIFSC). Coral reef ecosystem and habitat surveys in the Mariana Archipelago: Preliminary findings and key figures for the islands of Guam, Aguijan, Tinian, Saipan, and Pagan. Prepared by NOAA Coral Reef Ecosystem 
Division Pacific Islands Fisheries Science Center for U. S. Naval Facilities Engineering Command Pacific (NAVFAC Pacific). Honolulu, Hawaii.

[46] U.S. Government. 2011. NOAA. Technical Memorandum NMFS-PIFSC-27. Status Review Report of 82 Candidate Coral Species Petitioned Under the U.S. Endangered Species Act. Silver Spring, Maryland.

[47] U. S. Government. 2012. Seismic hazard assessment for Guam and the Northern Mariana Islands: U.S. Geological Survey Open-File Report, 2012-1015. Reston, Virginia.

[48] Van Treech, P., Schumacher, H. 1998. Mass diving tourism-a new dimension calls for new management approaches. Mar. Pollut. Bull. 37:8-12, 499-504.

[49] Veron, J.E.N. 2000. Corals of the World, Vols. 1, 2 \& 3. Australian Institute of Marine Science. Townsville, Australia.

[50] Wild, C., et al. 2005. Influence of coral mucus on nutrient fluxes in carbonate sands. Mar Ecol Prog Ser 287, 87-98.

[51] Worm, B., et al. 2006. Impacts of biodiversity loss on ocean ecosystem services. Science 314, 787-790.

[52] Zgliczynski, B. et al. 2008. Pacific-Wide Status of the Rare/Endangered Humphead Wrasse (Cheilinus undulatus) and Bumphead Parrotfish (Bolbometopon muricatum). Proc. 11th Int. Coral Reef Symposium (Abstract), 465-509. 